\title{
Deploying Anaerobic Digesters: Current Status and Future Possibilities
}

P. Lusk

International Energy Agency

P. Wheeler

ETSU (United Kingdom)

C. Rivard

National Renewable Energy Laboratory

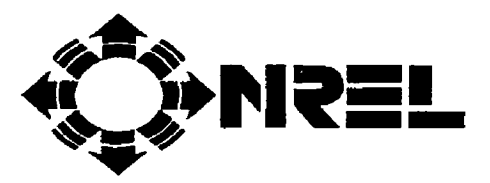

National Renewable Energy Laboratory 1617 Cole Boulevard Golden, Colorado 80401-3393

A national laboratory of the U.S. Department of Energy Managed by Midwest Research Institute for the U.S. Department of Energy under Contract No. DE-AC36-83CH 10093 


\section{Deploying Anaerobic Digesters: Current Status and Future Possibilities}

P. Lusk

International Energy Agency

P. Wheeler

ETSU (United Kingdom)

C. Rivard

National Renewable Energy Laboratory

\section{NPEL}

National Renewable Energy Laboratory

1617 Cole Boulevard

Golden, Colorado 80401-3393

A national laboratory of the U.S. Department of Energy Managed by Midwest Research Institute under Contract No. DE-AC36-83CH10093

Prepared under Task No. WM513231

January 1996 


\section{NOTICE}

This report was prepared as an account of work sponsored by an agency of the United States government. Neither the United States government nor any agency thereof, nor any of their employees, makes any warranty, express or implied, or assumes any legal liability or responsibility for the accuracy, completeness, or usefulness of any information, apparatus, product, or process disclosed, or represents that its use would not infringe privately owned rights. Reference herein to any specific commercial product, process, or service by trade name, trademark, manufacturer, or otherwise does not necessarily constitute or imply its endorsement, recommendation, or favoring by the United States government or any agency thereof. The views and opinions of authors expressed herein do not necessarily state or reflect those of the United States government or any agency thereof.

Available to DOE and DOE contractors from:

Office of Scientific and Technical Information (OSTI)

P.O. Box 62

Oak Ridge, TN 37831

Prices available by calling (615) $576-8401$

Available to the public from:

National Technical Information Service (NTIS)

U.S. Department of Commerce

5285 Port Royal Road

Springfield, VA 22161

(703) $487-4650$ 


\section{TABLE OF CONTENTS}

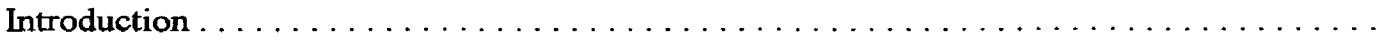

The Anaerobic Digestion Process, Christopher J. Rivard and David R. Boone . . . . . . 1

Animal and Industrial Waste Anaerobic Digestion: USA Status Report, Philip D. Lusk ...

Animal Manure Digestion Systems in Central Europe, Erwin Köberle

Anaerobic Digestion of Municipal Solid Waste: Technical Developments,

Christopher J. Rivard

Biogas Utilization, Mark A. Moser

Environmental Impacts of Anaerobic Digestion and the Use of Anaerobic Residues as a Soil Amendment, Frank E. Mosey 


\section{INTRODUCTION}

Unmanaged pollutants from putrescible farm, industrial, and municipal wastes degrade in the environment, and methane emitted from their decomposition may contribute to global climate change. Under modern environmental regulations, these wastes are becoming difficult to dispose of using traditional means. One waste management system, anaerobic digestion or $\mathrm{AD}$, not only provides pollution prevention but can also convert a disposal problem into a new profit center. This report is drawn from a special session of the Second Biomass Conference of the Americas.

\section{The AD Process}

$\mathrm{AD}$ is a biological process, where synergistic actions between bacteria are occurring at four different levels. First, hydrolysis converts a wide range of solid organic materials into sugars and amino acids. Fermenting these materials produces volatile fatty acids (VFAs). Acidogenesis forms hydrogen, carbon dioxide $\left(\mathrm{CO}_{2}\right)$, and acetate from VFAs. Finally, methanogenesis produces biogas, a mixture of methane, $\mathrm{CO}_{2}$, and numerous trace elements. The key biological issues are determining the most favorable conditions for each process stage and how nonoptimal circumstances affect the process as a whole, and the governing role of hydrogen generation and consumption.

\section{Technology Application}

Within the world of $A D$ technology, farm-based $A D$ facilities are perhaps the most common. A recent survey of farm manure facilities in the United States concluded that $\mathrm{AD}$ is a technology with considerable potential, and that 3000 to 5000 farm digesters could be economically deployed in the next decade. Farmers in the United States who now operate a digester often cite odor control and containing excess nutrient runoff as the drivers influencing their investment decision.

In Europe, $\mathrm{AD}$ facilities have had a good record in treating the spectrum of suitable farm, industrial, and municipal wastes. Some of these facilities have been in operation for more than 10 years. The key factor found in successful facilities is simplicity of design. Other factors influencing success have been local environmental regulations and other policies governing land use and waste disposal.

Most experience with large digestion facilities has been in Denmark. Recently, Denmark's commitment to $\mathrm{AD}$ increased with an energy initiative that will double biogas production by the year 2000, and then triple it by the year 2005 . One of the key policy tools used to encourage technology deployment is "green pricing," allowing manufacturers of biogasgenerated electricity to sell their product at a premium. Interestingly, sales of co-generated hot water to specially built district heating systems is becoming an important source of revenue. 
One new application is the digestion of municipal solid waste (MSW). Several systems have been developed; each has its own special benefits. Biological treatment processes such as $\mathrm{AD}$ offer the only route for recycling organic matter and nutrients from the putrescible fraction of MSW. However, $A D$ is the only biological treatment process that produces energy.

MSW digestion poses many technical problems. High-solid digestion (HSD) systems operating with concentrations greater than $30 \%$ have been developed. These systems have the potential to improve the economic merit by reducing digester volume and the parasitic energy required for the $\mathrm{AD}$ process.

\section{Energy and Environment}

Biogas is suitable for use in engines to generate electricity, boilers to produce hot water and steam, or in gas-fired absorption chillers used for refrigeration. When biogas is used to generate electricity, there is the added potential for harvesting thermal energy. Fuel cells are a new end-use application, and projects using biogas are currently under way in Asia, Europe, and North America.

Using the solid and liquid residues from the $A D$ process can also have very beneficial environmental impacts. $\mathrm{AD}$ enriches alternative agricultural practices when the residues are applied to crops or dedicated feedstocks for alternative fuels such as biodiesel or ethanol. Treating commodities to produce another energy yield while recycling nutrients creates a virtuous cycle of sustainability.

AD mitigates a number of other environmental concerns. The process reduces the potential for odors, destroys pathogens, and displaces fossil fuels. Further, increased atmospheric methane concentrations may have important impacts on global climate change. Methane is considered to be a potent greenhouse gas (GHG) because each molecule is estimated to have 22 times the heat-trapping impact of a $\mathrm{CO}_{2}$ molecule.

\section{Economic Merit}

As noted, $\mathrm{AD}$ is a technically feasible option. However, like most renewable energy options, its economic merit relies on a number of site-specific factors. The importance of selling the energy products produced from biogas at a satisfactory price cannot be overestimated. Generally, this means that $\mathrm{AD}$ facilities must negotiate suitable rate structures with an electricity utility, and maximize the use of the process heat.

There is a major barrier in negotiating utility power purchase contracts that will provide sufficient revenue. The problem is the "avoided cost" rates offered by utilities to independent power producers. In many nations, rates are typically low, in part because of 
current low prices for fossil fuels and, in some cases, due to the availability of excess generating capacity.

Individual national conditions such as energy prices, pollution taxes, and the cost of regulatory compliance strongly influence the economic merit of an $\mathrm{AD}$ system. Therefore, comparing individual facilities and countries is extremely difficult.

\section{Summary}

Successful deployment of $\mathrm{AD}$ facilities is site-specific. The factor most strongly influencing the economic merit of an $\mathrm{AD}$ facility is maximizing the sales of all usable coproducts, especially electricity. Legislation that helps internalize social cost is also important, but in practice, externalities are difficult to quantify. However, formal consideration of the true cost of the various energy options can only improve the economic merit of $\mathrm{AD}$ facilities; thus, evaluating total life-cycle cost is a major task in the near-term. Understanding total life-cycle cost by politicians and policy makers is important if renewable energy technology are to become truly competitive. 


\section{Acknowledgments}

Many thanks to the eight authors who prepared the original papers from which this report is drawn, and especially to $\mathrm{M} \mathrm{R}$ Hardee for editorial services.

\section{About the IEA AD Activity}

The $\mathrm{AD}$ activity aims to provide reliable information on the cost effectiveness of $\mathrm{AD}$, markets for biogas, and other co-products, more effective use of biogas, environmental benefits, and institutional barriers. Copies of the special session on $\mathrm{AD}$ are available from the National Renewable Energy Laboratory, 1617 Cole Boulevard, Golden, Colorado 80401-3393, USA. Document Distribution Code TP-427-20558. Tel: +1 303 275 4363; Fax: +13032753619 . 


\title{
THE ANAEROBIC DIGESTION PROCESS
}

\author{
Christopher J. Rivard, Ph.D., Senior Microbiologist \\ National Renewable Energy Laboratory, Golden, Colorado 80401 U.S.A. \\ David R. Boone, Ph.D. Professor of Environmental Microbiology \\ Oregon Graduate Institute, Portland, Oregon 97291-1000 U.S.A.
}

\begin{abstract}
The microbial process of converting organic matter into methane and carbon dioxide is so complex that anaerobic digesters have long been treated as "black boxes." Research into this process during the past few decades has gradually unraveled this complexity, but many questions remain. The major biochemical reactions for forming methane by methanogens are largely understood, and evolutionary studies indicate that these microbes are as different from bacteria as they are from plants and animals. In anaerobic digesters, methanogens are at the terminus of a metabolic web, in which the reactions of myriads of other microbes produce a very limited range of compounds-mainly acetate, hydrogen, and formate-on which the methanogens grow and from which they form methane. "Interspecies hydrogen-transfer" and "interspecies formate-transfer" are major mechanisms by which methanogens obtain their substrates and by which volatile fatty acids are degraded. Our understanding of these reactions and other complex interactions among the bacteria involved in anaerobic digestion is only now to the point where anaerobic digesters need no longer be treated as black boxes.
\end{abstract}




\section{The Anaerobic Bioconversion Process}

Metabolic life in the absence of oxygen has to be frugal. Anaerobic microbes have had to adapt to life with less available energy. An example of this is the conservation of the original energy content of organic substrates in the methane end-product (greater than 90\%). As such, the anaerobic process has several distinct advantages such as the production of low levels of microbial biomass, which thereby reduces the need for essential nutrients. However, this low level of microbial catalyst production often results in process instability because of microbial washout or enhanced sensitivity to process perturbations.

The anaerobic digestion process takes place through the synergistic action of four types of microorganisms: hydrolytic, fermentative, acidogenic, and methanogenic bacteria. Numerous reviews describe the level of understanding of the anaerobic digestion process and the terminal steps of methane production ${ }^{1-10}$. The hydrolytic bacteria in these consortia produce a variety of enzymes to depolymerize such constituents as cellulose, proteins, pectins, hemicellulose, and starches to monomeric subunits such as sugars or amino acids. The fermentative bacteria convert these monomers to organic acids, primarily propionic and acetic acid. The acidogenic bacteria convert these acids to hydrogen, carbon dioxide, and acetate, which the methanogens utilize via two major pathways to produce methane and carbon dioxide.

Because of the relatively low level of free energy available in most anaerobic fermentations, microbial communities evolve as symbiotic relationships to help pull metabolic reactions toward more favorable conditions. Often microbial communities must be developed to achieve overall biological decomposition. These communities at the same time protect the more sensitive participants within the community, thereby increasing the stability of the process to perturbations.

\section{Historical Perspective}

Early awareness of methane generated during anaerobic processes was recorded as mysterious flickering flames in swamps and marshlands known as "will-o-wisp" ${ }^{1}$ " Van Helmont in 1630 first determined that flammable gases could evolve from decaying organic matter. In 1776, Volta concluded that there was a direct correlation between the amount of decaying organic matter and the amount of flammable gas emitted. He also determined that certain proportions of this flammable gas were explosive in air. In 1808, Davy determined that methane was present in the gases produced during the anaerobic digestion of cattle manure. In 1868, Bechamp, a student of Pasteur', attempted to isolate the microorganism responsible for the anaerobic bioconversion of ethanol to methane. In reality, Bechamp's attempts resulted in a co-culture of microorganisms ${ }^{12}$.

The first practical application of anaerobic digestion for energy production took place in England in 1896 when biogas from sewage sludge digestion was used to fuel street lamps. Since that time, the process has received considerable interest to harness its energyproducing capabilities. Applied research began with Buswell's work in the 1920s in 
which he established fermentation stoichiometries, the fate of nitrogen, and developed farm-scale digestion systems ${ }^{13.14}$. Since that time, numerous studies and demonstration projects have been attempted with the widest application of anaerobic bioconversion for the disposing municipal sewage.

\section{Carbon flow}

In general, the anaerobic biological process yields consistent end-products, including methane, carbon dioxide, microbial biomass, and recalcitrant organics. The effective conversion of feedstock carbon requires the concerted effort of a variety of microorganisms. The anaerobic process appears to proceed uniformly toward methane production, but even transient inhibition of one participating consortium group may create an imbalance that causes intermediary products (primarily organic acids) to accumulate, thereby reducing sludge $\mathrm{pH}$ and ultimately inhibiting more sensitive microbes in the consortium and throwing the process into a "sour" condition. Process monitoring is thus important to ensure stable bioconversion. Monitoring biogas production, biogas methane content, sludge volatile solids destruction, sludge volatile organic acid levels, and $\mathrm{pH}$ is important to predict the general health of the digester process.

\section{Microbiology}

Substantial understanding of the microorganisms that participate in the anaerobic consortium exists, however, this information is far from complete. In general, microbial populations within the digester consortium are fluctuate continuously, depending on such factors as changes in feedstock composition, organic loading rate, nutrient availability, presence of inhibitors or stimulants, environmental parameters such as $\mathrm{pH}$ and volatile fatty acid levels, and end-product concentrations. In addition, thermophilic and mesophilic microbes may be present at varying populations in a mesophilically operated digester ${ }^{15}$. This allows such digestion systems to adapt to thermophilic conditions without being inoculated by thermophilic microorganisms. A rather slow adaptation period will allow the thermophilic microorganisms to predominate under the new conditions ${ }^{16}$.

\section{Native hydrolytic enzyme systems}

The methanogenic and acetigenic bacteria have slower maximal growth rates than do the hydrolytic and fermentative bacteria, but when conditions in digestors are maintained to avoid "sour digestor," their metabolism does not limit the rate and extent of digestion?. The rate-limiting step in the anaerobic bioconversion of polymeric feedstocks such as agricultural residues or MSW is polymer hydrolysis. Hydrolytic enzymes are required to depolymerize feedstocks such as hemicellulose, cellulose, starch, pectin, proteins, fats, oils, and greases. In their monomeric form these molecules may be taken up by the fermentative microbes and converted to smaller molecular weight organic acids. In general, hydrolytic enzyme productivity by anaerobes is quite low compared to aerobic hydrolytic microbes, partly because of the low-level energy yield from anaerobic metabolism. With lower levels of hydrolytic enzymes present, the rate of polymer degradation in anaerobic systems is anticipated to be slower than aerobic system for polymeric feedstocks. Engineering digester systems to "cater" to the hydrolytic microbes is one way to improve the rate of feedstock polymer hydrolysis. Whereas methanogenic bacteria prefer a $\mathrm{pH}$ in slightly greater than neutral, hydrolytic microbes and their enzyme 
systems operate best at $\mathrm{pH}$ levels of 6 to 6.8 . In addition, the optimum temperature for hydrolytic enzyme activity is often closer to $40^{\circ} \mathrm{C}$ as opposed to the optimum for most mesophilic microorganisms of $35^{\circ} \mathrm{C}$ to $37^{\circ} \mathrm{C}$. Designing reactors to enhance the hydrolysis phase of anaerobic digestion takes advantage of these optima by separating the hydrolysis from methanogenic stages of the digestion process (two-stage digestion) and operating each phase under optimum conditions of temperature and $\mathrm{pH}$.

Another approach to enhancing the rate of polymer hydrolysis is to increase the contact time for hydrolytic enzymes when treating polymeric feedstocks. This may be accomplished using systems that allow for separate control of hydraulic and solids retention times or through high-solids digestion systems that contain very little free water. An additional benefit of high-solids systems is derived from the low rate of mixing in these systems, in which shear forces which may disrupt the enzyme-substrate binding are minimized.

\section{Interspecies hydrogen transfer}

As described above, the overall conversion of organic feedstocks to methane and carbon dioxide is a result of the synergistic action of a consortium of microorganisms. The ability to enhance the metabolic energy derived from anaerobic fermentations is a feature of this relationship. When organic substrates are anaerobically fermented, electrons are "dumped" in the form of dihydrogen. Unless these electrons are actively removed subsequent fermentation reactions become unfavorable. This is especially true for reactions with minimal free energy potential. The ability to maintain extremely low partial pressure of dihydrogen is imperative to pull the anaerobic conversion process to completion. Dihydrogen utilization is a competitive process in which methanogens and sulfate reducers are the key participants. Table 1 describes the level of free energy that may be expected from oxidizing of dihydrogen at the expense of nitrate, sulfate, and dissolved carbon dioxide.

Table 1. Comparison of Free Energy for Dihydrogen Oxidation by Various Electron Acceptors

\begin{tabular}{|c|c|}
\hline Electron Acceptor & Free Energy $\left(\mathrm{G}^{\mathrm{o}^{\circ}}\right)$ \\
\hline \hline Nitrate & -143.3 \\
Sulfate & -36.3 \\
Carbonate & -32.4 \\
\hline
\end{tabular}

\section{Feedstock effects}

Various feedstock parameters directly affect the yield and quality of the biogas product. In 1933, Symons and Buswell established an equation to determine the theoretical methane yield that may be expected from the known composition of the feedstock. Later, 
Owen et al. (1979) established a more useful relationship for theoretical methane yield for a given feedstock based on the chemical oxygen demand value ${ }^{17}$. In general this relationship states that for $100 \%$ conversion efficiency that one gram of substrate carbon oxygen demand will result in $350 \mathrm{~mL}$ of methane at standard temperature and pressure.

One aspect of the Symons and Buswell conversion equation is that feedstocks with increased carbon to oxygen ( $\mathrm{C}: \mathrm{O})$ ratios will result in a higher percentage of methane in the product biogas. As the value of the biogas product is often based on the Btu content of the biogas (a direct reflection of the methane content), converting more reduced feedstocks such as those that contain fat, oil, and grease will ultimately result in a higher value fuel gas product.

Feedstock size reduction also affects the hydrolysis rate for polymeric feedstocks. Smaller particle sizes increase the surface area for microbial attack by hydrolytic enzymes.

\section{Engineering the "Black Box"}

With our increased knowledge of the microbial participants and metabolic interdependence of the anaerobic digestion process, we can now more fully exploit the process to its maximum potential. The anaerobic digestion of lignocellulosic materials, such as municipal solid waste and biomass, is limited by the rate of polymer hydrolysis ${ }^{9,18}$. The primary biodegradable polymer in biomass, cellulose, is shielded by lignin, a relatively inert, polyphenylpropane, three-dimensional polymer ${ }^{19}$, and by hemicellulose $^{20}$. This complex structure dictates that under natural environmental conditions this biodegradation occurs over months or years, rather than hours or days. Anaerobic digestion of such materials in completely mixed digestors requires a long contact time between microbes and substrate to obtain satisfactory yields. This results in very long retention times, reactor volumes, and thus capital costs in large-scale application. We now have devised systems such as sequencing batch reactors, high-solids anaerobic digesters, or multiple-phase digester systems that increase the solids retention time and hydrolytic microbial contact, or optimize the environmental conditions for the hydrolytic process.

Readily solubilized and fermentable substrates impose a different limitation, that of organic acid conversion. Improved process understanding has led to the designed systems that use immobilization to increase the relative concentration of slow-growing acetogenic and methanogenic microbes. Fixed film or granulation reactors retain these microorganisms in the digester system and protect these more sensitive microbes by producing microbial films ${ }^{21}$.

In general, our knowledge of process design, monitoring, and control allow current anaerobic digestion systems to be operated more closely to their theoretical optimum, and often with well-defined biological conversion efficiencies. 


\section{References}

1. Buswell, A.M., and Hatfield, W.D. (1936), Anaerobic Fermentations, State of Illinois Department of Registration and Education Bulletin, Chicago, 32.

2. McCarty, P.L. (1964), Public Works 95, 107.

3. Wolfe, R.S. (1971), Microbial Formation of Methane. Adv. Microbial Physiol. 6, 107-145.

4. Mah, R.A.; Ward, D.M.; Baresi, L.; Glass, T.L., (1977), Biogenesis of Methane. Ann. Rev. Microbiol. 31, 309-341.

5. Zeikus, J.G., (1977), The Biology of Methanogenic Bacteria. Bacteriol. Rev. 41, 514-541.

6. Balch, W.E., Fox, G.E., Magrum, L.J., Woese, C.R., and Wolfe, R.S. (1979) Microbiol. Rev. 43, 260.

7. Bryant, M.P. (1979), Microbial Methane Production: Theoretical Aspects. $J$. Animal Sci. 48, 193-201.

8. Clausen, E.C.; Sitton, O.C.; Gaddy, J.L. (1979), Biological Production of Methane from Energy Crops. Biotech. Bioeng. 21, 1209-1219.

9. Boone, D.R. (1982), Terminal Reactions in the Anaerobic Digestion of Animal Waste. Appl. Environ. Microbiol. 43, 57-64.

10. Daniels, L.; Sparling, R.; Sprott, G.D. (1984), The Bioenergetics of Methanogenesis. Biochem. et Biophys. Acta 768, 113-163.

11. McCarty P.L. (1982), One Hundred Years of Anaerobic Treatment. In Anaerobic Digestion 1981, Proceedings of the 2nd Symp. on Anaerobic Digestion, Travemunde, Germany, Sept. 6-11, pp 3-22.

12. Zehnder, A.J.B.; Ingvorsen, K.; and Marti, T. (1982), Microbiology of Methane Bacteria. In Anaerobic Digestion 1981, Proceedings of the 2nd Symp. on Anaerobic Digestion, Tavemunde, Germany, Sept. 6-11, pp 45-68.

13. Buswell, A.M. and Neave, S.L. (1930), Laboratory Studies of Sludge Digestion. State of Illinois, Dept. of Registration and Education, Div. of the State Water Survey, Urbana, Illinois, Bulletin No. 30, pp 1-84.

14. Metcalf \& Eddy, Inc. (1979), Wastewater Engineering: Treatment, Disposal, Reuse, New York: McGraw-Hill

15. Zhao, Y., H. Zhang et al 1986, Appl. Env. Micro.

16. Zinder, S.H.; Anguish, T.; and Cardwell, S.C. 1984.

17. Owen, W.F.; Stuckey, D.C.; Healy, J.B.; Young, L.Y.; and McCarty, P.L. (1979), Bioassay for Monitoring Biochemical Methane Potential and Anaerobic Toxicity. Water Res. 13, 485-492.

18. Noike, T.; Endo, G.; Chang, J-E.; Yaguchi, J-I.; Matsumoto, J-I. (1985), Characteristics of Carbohydrate Degradation and the Rate-Limiting Step in Anaerobic Digestion. Biotechnol. Bioeng. 27, 1482-1489.

19. Sarkanen, K.V. and Ludwig, C.H. (1971), Lignins: Occurrence, Formation, Structure and Reactions. Wiley-Interscience, New York, NY.

20. Grohmann, K., Torget, R., Himmel, M.E. (1985) Biotech. Bioeng. Symp. 15:59-80.

21. Young, J.A. and McCarty, P.L. (1965), The Anaerobic Filter for Waste Treatment. J. Water Pollut. Control Fed. 41, R160-R171. 


\title{
ANIMAL AND INDUSTRIAL WASTE ANAEROBIC DIGESTION: USA STATUS REPORT
}

\author{
Philip D. Lusk, Principal \\ Resource Development Associates, Washington, DC 20002 USA
}

\begin{abstract}
Pollutants from unmanaged animal and bio-based industrial wastes can degrade the environment, and methane emitted from decomposing wastes may contribute to global climate change. One waste management system prevents pollution and converts a disposal problem into a new profit center. Case studies of operating systems indicate that the anaerobic digestion of animal and industrial wastes is a commercially available bioconversion technology with considerable potential for providing profitable coproducts, including a cost-effective renewable fuel. Growth and concentration of the livestock industry create opportunities to properly dispose of the large quantities of manures generated at dairy, swine, and poultry farms. Beyond the farm, extension of the anaerobic digestion process to recover methane has considerable potential for certain classified industries with a waste stream characterization similar to livestock manures. More than 35 example industries have been identified, and include processors of chemicals, fiber, food, meat, milk, and pharmaceuticals. Some of these industries already recover methane for energy. This status report examines some current opportunities for recovering methane from the anaerobic digestion of animal and industrial wastes in the U.S. Case studies of operating digesters, including project and maintenance histories, and the operator's "lessons learned," are included as a reality check. Factors necessary for successful projects, as well as a list of reasons explaining why some anaerobic digestion projects fail, are provided. The role of management is key; not only must digesters be well engineered and built with high-quality components, they must also be sited at facilities willing to incorporate the uncertainties of a new technology. Anaerobic digestion can provide monetary benefits and mitigate possible pollution problems, thereby sustaining development while maintaining environmental quality. Moreover, economic development will benefit from the implicit multiplier effect resulting from jobs created by implementing digester systems. Promising future waste-to-profit activities may add to the economic performance of anaerobic digestion. New end-use applications that provide added value to coproducts are discussed.
\end{abstract}




\section{Introduction}

Growth and concentration of livestock production and certain classified industries in the U.S. create new opportunities to properly dispose of waste materials generated at these facilities. Principal pollutants from decomposing organic wastes are methane emissions, ammonia, and excess nutrients and pathogens, along with biochemical oxygen demand. The major pollution problems associated with these wastes are surface and ground water contamination, and surface air pollution caused by odors, dust, volatile organic acids, and ammonia. There is also concern about the contribution of methane emissions to global climate change. Consequently, waste management systems that enable pollution prevention and energy production are becoming increasingly attractive.

The anaerobic digestion of animal and bio-based industrial wastes is a commercially available conversion technology with considerable potential for providing profitable coproducts, including a cost-effective renewable fuel. Anaerobic digesters are commonly designed to operate in either the mesophilic temperature range $\left(20^{\circ} \mathrm{C}\right.$ to $\left.45^{\circ} \mathrm{C}\right)$ or the thermophilic temperature range $\left(45^{\circ} \mathrm{C}\right.$ to $\left.60^{\circ} \mathrm{C}\right)$. There are usually two reasons why these temperature ranges are preferred. First, a higher loading rate of organic materials can be processed, and because shorter retention times are associated with higher temperatures, increased outputs for a given digester capacity result. Second, a higher temperature increases the destruction of pathogens present in raw manure. Anaerobic digestion also occurs in the psychrophilic temperature range (less than $20^{\circ} \mathrm{C}$ ), but this region has not been as extensively evaluated by the research community.

Some effort has focused on the anaerobic digestion of poultry manures, but the manures from dairy and swine operations have been used more extensively for farm-based energy conversion. Dairy and swine manure management systems are often liquid- or slurrybased, which simplifies the necessary manure movement. Also, poultry manures contain a higher concentration of fine solids that can quickly fall out of suspension if not continuously agitated. Built-up solids can reduce reactor and biogas production volumes. The three main types of anaerobic systems used on farm in the U.S. include the complete mix, plug flow, and low-temperature covered anaerobic lagoon digesters.

Anaerobic digestion is ideally suited for many of the concentrated wastewaters typical of many industrial processes today. More than 35 example industries have been identified with wastewaters amenable for anaerobic treatment, including processors of chemicals, fiber, food, meat, milk, and pharmaceuticals. The types of anaerobic digesters commonly used in industrial applications in the U.S. include low-temperature covered lagoons, complete mix, packed reactors, upflow sludge blankets, and sequencing batch reactors. The advantages of these technologies compared to other biologically-based processes include low sludge production, high removal efficiencies, low nutrient requirements, low maintenance, and, of course, biogas production.

Biogas produced by the anaerobic digestion process is quite similar to "natural" gas, as it is extracted from the wellhead and is suitable for use in engine/generators to produce electricity. When biogas is used to produce electricity, there is the added potential for harvesting thermal energy from the engine's exhaust and cooling systems. ${ }^{1}$. Biogas can also be burned in boilers to produce hot water and steam used for sanitary washing, or 
in gas-fired absorption chillers used for refrigeration ${ }^{2}$. Some digesters successfully compress the biogas to operate light-duty vehicles as well.

Promising future waste-to-profit activities may enhance the economic performance of the overall waste management system. One new end-use application that can provide added value to coproducts is the fuel cell for generating electricity and process heat. Fuel cells appear to offer a particularly clean and effective method of converting biogas into electricity and process heat. Instead of the 20\%-25\% electrical conversion efficiency from today's engine/generator technologies, fuel cells could produce electricity from biogas at a $40 \%-50 \%$ conversion efficiency, a two fold increase in productivity. When combined with process heat recovery, overall fuel cell efficiency is greater than $80 \%$. Because of their high efficiency, fuel cells emit less carbon dioxide per kilowatt hour of electricity than do current conversion technologies. The process also produces a minimal amount of carbon monoxide and nitrogen oxides, an issue of extreme importance to areas with substandard classifications under the Clean Air Act Amendments of 1990. With no moving parts, fuel cells also operate very quietly. Around 60 units that operate on natural gas̄ have been sold world-wide. Two fuel cell projects using biogas are currently under way: one will demonstrate biogas recovery from a landfill in California, and the other will recover biogas from a wastewater treatment facility. The second project will also reclaim waste heat for use by the facility's anaerobic digester.

The economic performance of the overall farm manure management system may be enhanced by adding value to coproducts and maximizing nutrient utilization in greenhouses, and production of algae, plant, and fish aquaculture. Following the digestion process, diluted wastewater effluent can be used as a nutrient source for hydroponic plant culture in attached greenhouses. Additionally, attached greenhouses can provide enhanced plant growth rates if the available carbon dioxide is captured. Discharged wastewater effluent can also be discharged into ponds and used as a growth culture for algae or aquatic plants. Algae are up to $50 \%$ protein and can be used for many purposes. Currently, algae are produced for animal feed and as a soil amendment. One alga that can be grown is Spirulina, a super-nutrient that contains large amounts of beta-carotene. It is a lipid-rich alga that can be converted into a liquid diesel fuel substitute. Other algae can be used as natural colorants or dyes. Some species of duckweed, an aquatic plant that contains $35 \%-45 \%$ protein and has properties similar to algae, have phenomenal growth rates when grown in waste effluents. Fresh duckweed has been used as fish food with good results, and dried duckweed meal has been an excellent substitute for soy and fish meals in poultry rations ${ }^{3}$.

\section{Farm-Based Anaerobic Digestion ${ }^{4}$}

The energy requirements of larger-sized American livestock operations led to the design and installation of several digesters using model municipal sewage treatment plant technology as one response to the energy crises of the 1970s. These demonstration projects represented a transfer of state-of-the-art sewage treatment plant technology and were the first generation of complete mix digesters installed for agricultural applications. Although complete mix digesters can operate in the thermophilic temperature range, the demonstration projects at facilities such as the Washington State Dairy Farm in Monroe operated only in the mesophilic temperature range. At the Monroe project, the digester 
was sized for the manure volume produced by a milking herd of 180 to 200 Holstein cows. Although these early complete mix digesters generally produced biogas at the target design rate, they suffered from high capital costs and from significant operation and maintenance requirements. In practical application on the farm, the issues of solids settling, scum formation, and grit removal often presented major problems.

Today's complete mix digesters typically handle manure with a low solids content and generally can handle substantial manure volumes. The reactor is a large, vertical, poured concrete or steel circular container. The manure is collected in a mixing pit by either a gravity-flow or pump system. The total solids percentage can be diluted, and the manure can be pre-heated before it is introduced to the digester reactor. The manure is deliberately mixed in the digester reactor. The mixing process creates a homogeneous substrate that prevents the formation of a surface crust and keeps solids in suspension. Mixing and heating often improve digester efficiency. This "medium-rate" digestion technology usually has a hydraulic retention time (HRT), the total time that manure spends inside the digester, from 10 to 20 days.

A fixed cover is placed over the complete mix digester reactor to maintain anaerobic conditions and to trap the methane that is produced. The methane is removed from the digester, processed, and transported to the site of end-use application. The most common application for methane produced by the digestion process is electricity generation using a modified internal combustion engine. Both the digester reactor and the mixing pit are heated with waste heat from the engine cooling system. As already mentioned, complete mix digesters operate at either the mesophilic or thermophilic temperatures ranges. Lower temperatures reduce the rate of methane production, and consequently, a digester operated in the mesophilic range requires a longer average manure retention time and a larger tank. Complete mix digester volumes range considerably from about 3500 cubic feet to 14,000 cubic feet. This represents daily capacities of about 25,000 gallons to 100,000 gallons of manure per digester. Larger volumes are usually handled by multiple digesters.

By the late-1970s researchers at Cornell University ${ }^{6}$ were able to reduce the capital costs and the operational complexities associated with the early complete mix digesters by using a simple extension of Asian anaerobic digestion technology. These "plug flow" digesters were adopted with some success in the cooler climate of the Northeast, where farms primarily use scraping systems to remove manure. The 1979 project at the Mason Dixon Dairy Farms in Gettysburg, Pennsylvania was the first plug flow digester operated on a commercial farm. At the Mason Dixon project, the plug flow digester was originally sized for a manure volume produced by a milking herd of 250 Holstein cows.

The basic plug flow digester design is a long linear trough, often built below ground level, with an airtight expandable cover. The manure is collected daily and added at one end of the trough. Each day a new "plug" of manure is added, slowly pushing the other manure down the trough. The size of the plug flow system is determined by the size of the daily "plug." As the manure progresses through the trough, it decomposes and produces methane that is trapped in the expandable cover. To protect the flexible cover and maintain optimal temperatures, some plug flow digesters are enclosed in simple greenhouses or insulated with a fiberglass blanket. The HRT is from 20 to 30 days depending on the digester temperature. An often vital component of a plug flow digester 
is the mixing pit, which allows the percent total solids of the manure to be adjusted by dilution with water. Many systems use a mixing pit with a capacity roughly equal to one day's manure output to store manure before adding it to the digester.

Plug flow digesters operate at either the mesophilic or thermophilic temperature ranges. The amount of methane produced depends on the quantity of manure and the average retention time in the trough. Lower temperatures will slow the rate of digestion, which will require a longer retention time, and consequently, a larger, more expensive trough. Higher temperatures will increase the digestion rate which allows a shorter retention time and a smaller, less expensive trough. Energy for heating the digester is available in the waste heat from the exhaust and cooling system of an internal combustion engine/generator powered by the biogas produced in the digester.

The complete mix and plug flow digestion technologies are not suited for use on farms that use hydraulic flushing systems to remove manure. Instead an anaerobic lagoon is an increasingly popular method used to store and treat manure. A properly designed and operated lagoon system, where the manure retention time exceeds 60 days, will produce significant quantities of methane. In the early 1980s, the concept of using a floating cover that collects biogas as it escapes from the surface of an anaerobic lagoon emerged. The first floating cover that recovered biogas from an anaerobic lagoon operating in the psychrophilic range was at the Royal Farm operation in Tulare, California ${ }^{7}$. The Royal Farm's digester used the manure from a 1,600-sow farrow-to-finish farm.

The North Carolina Energy Division and North Carolina State University constructed the first full-scale covered anaerobic lagoon digester on the east coast at the Randleigh Dairy in $1988^{8}$. The digester processed the wastes from 150 dairy cows. The cooperative project used funds provided by the U.S. Department of Energy's Southeastern Regional Biomass Energy Program, the North Carolina Agricultural Research Service, and the North Carolina Dairy Foundation. The project objective was to educate dairy producers through practical demonstration and outreach about the merits of a low-cost and easily maintained digester suitable for use on farms using hydraulic flush manure management systems. The project provided information about the amount of biogas that can be recovered, along with cost information from which the economic merit of the technology can be evaluated.

The methane produced in an anaerobic lagoon is captured by placing a floating, impermeable cover over the lagoon. The cover is constructed of an industrial fabric such as hypalon that rests on solid floats laid on the surface of the lagoon. The cover can be placed over the entire lagoon or over the portion of the lagoon that produces the most methane. Once the cover is installed, the methane produced under the covered area of the lagoon is trapped. The biogas is harvested using a collection manifold, such as a long perforated pipe, that is placed under the cover along the sealed edge of the lagoon. Methane is removed by the pull of a slight vacuum on the collection manifold (e.g., by connecting a suction blower to the end of the pipe) that draws the collected biogas from under the cover and on to the end-use application. The cover is held in position with ropes and anchored by a concrete footing along the edge of the lagoon. Where the cover attaches to the edge of the lagoon, an airtight seal is constructed by placing a sheet of the cover material over the lagoon bank and down several feet into the lagoon, and clamping 
the cover (with the footing) onto the sealed bank. Seals are formed on the remaining edges by using a weighted curtain of material that hangs vertically from the edge of the floating cover into the lagoon. The HRT of a "low-loaded" covered lagoon digester is measured in weeks or months, depending on the specific application and digester design. At Randleigh Dairy, the HRT was 67 days.

The covered lagoon digester has several merits. First, it has good potential for widespread adoption in the U.S., especially in the southeastern and southwestern regions, because most dairy and swine facilities use hydraulic flushing to collect manure and anaerobic lagoons to treat waste. Second, constructing and managing this type of reactor are simple and straightforward compared to complete mix and plug flow digesters. Third, the capital costs for this type of digester are considerably less than those required for the complete mix and plug flow types of conventional digesters.

Covering an anaerobic lagoon and harvesting the biogas is a simple technology; however, the approach raises at least two significant concerns. A key issue is that digestion rate depends on temperature; therefore, biogas production varies seasonally if the lagoon is not externally heated. This means that methane production is highest during the warm, summer months and lowest during the cooler, winter months. At the Randleigh Dairy, daily biogas production during the summer averaged $35 \%$ greater than daily production during the winter. This may make end-use applications more problematic than with conventional digesters that have fewer significant seasonal variations in methane production. Moreover, any anaerobic lagoon (covered or not) is impractical in areas with a high water table because of the potential for groundwater contamination. Lagoons built into highly permeable soils must be adequately lined to prevent groundwater contamination.

Mason Dixon Farms has since grown to a total herd of 2,000 milking cows and has built two additional digesters to accommodate the increased manure volume. Mason Dixon Farms has now abandoned the linear plug flow approach. The greatly simplified slurrybased "loop" digester now employed further minimizes digester construction and operating costs. This loop design enables greater convective currents in the digester, thereby avoiding the solids crusting problem commonly associated with the plug flow design. This improvement may offer a better opportunity for deploying loop digesters at caged-layer poultry operations.

A number of other methods for on-farm anaerobic digestion have been proposed, including variations of covered anaerobic lagoons generally referenced as Advanced Integrated Pond Systems (AIPS) ${ }^{9}$. AIPS use a submerged canopy covering a facultative pond, where the organic wastes are completely converted into methane, nitrogen, carbon dioxide, and stable residues. The submerged canopy is potentially more cost-effective than conventional covered lagoons because it is not exposed to weather and other elements. One intriguing aspect of AIPS is that digester effluent is discharged into secondary pools and is expressly used as a growth culture for algae.

Surveyed farmers who continue to operate one of the 25 remaining anaerobic digesters installed on dairy, swine, and poultry farms are generally satisfied with their investment decision. Some chose to install a digester for noneconomic reasons, primarily to control 
odor or contain excess nutrient runoff. Those farmers have found that the returns provided from electricity and other coproduct sales from the digester, however limited, are preferred to the sunk-cost of conventional disposal which provides no return on investment. Moreover, without the environmental benefits provided by anaerobic technology, some might have been forced out of livestock production. Anaerobic digestion is sometimes the key technology that allows growth in the livestock production business. Turning a waste liability into a profit center that generates annual revenues can moderate the impacts of declining commodity prices and diversify farm income.

None of the farmers surveyed to date with an operating anaerobic digester said that they regret their basic decision. Most would have preferred to spend less money on its design and installation, but they are unsure of exactly how costs could have been cut. Many seek new ways to increase profitability by the selling of coproducts, primarily the digested solids. They would like additional assistance in determining how best to optimize the added value of coproducts. Beating the odds, a few have met the challenge of making their systems work despite bad design or equipment. The hard knock of practical experience makes them the true superstars of farm-based anaerobic digestion technology in the U.S.

Of the conversion systems evaluated to date, slurry-based designs may offer the most benefits beyond their low cost to install and simplified operation. When combined with a mechanical scraping system to collect manure, there is little added water compared to hydraulic flushing. Because the organic acids are not volatilized, the methane and odor associated with manure decomposition can be minimized to the greatest extent possible. Emission rates for manure that decomposes in water can be as high as $90 \%$ of the total methane potential ${ }^{10}$. Covered lagoon digesters appear to have great economic merit for the large number of swine and dairy operations in the Southeast and West that incorporate hydraulic flushing for manure collection and conventional anaerobic lagoons for waste treatment. Plug flow digestion is economically sensitive to coproduct utilization and other offsets from current manure management practices. It is less expensive and technically easier to operate and maintain than a comparable complete mix digester, but the real world performance of plug flow digesters should make any potential investor wary of this approach. Complete mix digesters have higher capital costs and operating and maintenance requirements than covered lagoon and plug flow digesters. This will generally limit complete mix digester applications to very large farms and centralized facilities that have waste streams with total solid concentrations too low for slurry or plug flow digestion and to locations where the climate is too cold to economically justify covering a lagoon.

\section{Classified Industry Anaerobic Digestion"11}

Beyond the farm, extending the anaerobic digestion process to recover methane has considerable potential for certain classified industries with a waste stream characterization similar to livestock manures. More than 35 example bio-based industries have been identified, and include processors of chemicals, fiber, food, meat, milk, and pharmaceuticals. Many of these industries use anaerobic digestion as a pretreatment step to lower sludge disposal costs, control odors, and reduce the costs of final treatment at a municipal wastewater treatment facility. From the perspective of the municipal facility, 
pretreatment effectively expands existing treatment capacity. Although it is a common practice to flare any recovered biogas beyond that required for digester heating, some of these industries already recover methane for displacing on-site energy requirements.

Some of the types of industries that use anaerobic digestion technology to treat wastewater include alcohol, baker's yeast, bakery, brewery, candy, canneries, chemical, chocolate, citric acid, coffee, dairy and cheese, distillery, fermentation, fruit juice, fructose production, pulp and paper, pharmaceutical, potato processing, rubber production, sludge liquor, slaughterhouse, soft drinks, starch (barley, corn, wheat), sugar processing, vegetable and fruit, and yeast. Because all the technologies examined were initially commercialized for food processing applications, it is not surprising that this type of industry is the leader in using anaerobic treatment. The pulp and paper industry, including recycle mills, is a distant second as an industry category, and all others comprise only $10 \%$ or less of the totals. However, a great potential exists for the future anaerobic treatment of wastewater in the chemical and pharmaceutical industries.

The use of anaerobic technology offers several advantages over aerobic waste digestion. Using aerobic digestion, an appreciable fraction of the waste is converted to new biomass solids, leading to a potential coproduct disposal problem. In contrast, anaerobic digestion converts tenfold fewer solids, and the difference is converted to biogas with energy value. There also are favorable operation and maintenance benefits associated with anaerobic digestion technology that normally include lower energy requirements for operation. Certain types of anaerobic digestion processes can be extremely space efficient because they achieve higher loading rates than is usually possible with "conventional" aerobic processes. On the other hand, the anaerobic digestion of organic matter is normally not as complète as can be obtained through aerobic digestion, and, at least in the treatment of industrial wastewater, it is sometimes advantageous to combine anaerobic "pretreatment" with an aerobic polishing step.

The oldest and simplest form of anaerobic digestion technology employed by classified industries is the uncovered, unmixed lagoon. To make practical use of the lagoon technology and shorten the digestion time requirements, mixing methods were devised to improve the contact between the organic matter and the bacterial biomass, and a cover to collect biogas was added. This mixed and covered lagoon is now widely used to treat industrial wastes. As noted earlier, the HRT is measured in weeks or months, depending on the specific application and digester design.

Concurrently with efforts to improve the design of the anaerobic lagoon, work progressed on developing a completely mixed (stirred) tank reactor. This "CSTR" or "contact" process became the standard of the industry during the 1970 s, possibly because of its similarity to the conventional activated sludge aerobic processes widely used to treat municipal (domestic) wastewater. The CSTR reactor contains a mixer to maintain good contact between biomass and the organic material to be digested, and a post-clarification step with biomass return to ensure a steady quantity of mixed liquor suspended solids (MLSS) within the reactor. This "medium-rate" digestion technology usually has an HRT measured in days, so it typically offers greater space efficiency than lagoon technology. 
The anaerobic filter was commercialized in the late 1970s and, as the name implies, relies on a media substrate to retain the biomass in the reactor vessel. Different types of substrate materials have been used for this purpose, and, in efforts to reduce the possibility of plugging, different "flush-out" methods have been developed. These filters are operated either in an upflow mode or in the less common downflow mode, depending on the manufacturer. The HRT is typically a day or two, generally making these types of system somewhat more space efficient than the contact system.

The Upflow Anaerobic Sludge Blanket (UASB) process which basically combined the well-mixed attributes of the contact system with an internal biogas separation and clarification mechanism to eliminate the need for an external biomass return loop, was also a development of the mid and late 1970s. The mixing within the reactor results from the gassing that occurs as the organic components are distributed in the biomass bed at the bottom. A convection circulation is established that consists of an upward flow of gasborne biomass and a return downward flow of degassed biomass. The reactor contains no mechanical components, but does have a topworks baffle arrangement that separates the gas, liquid, and solid phases. The HRT in the UASB reactor is typically measured in less than a day, making it more space efficient than any system discussed previously. The very fast HRT, however, works against efficient digestion of organic material by forming suspended solids.

The fluidized bed anaerobic technology was also developed during the late 1970s in an effort to improve on loading rates and reduce reactor size even further. In this type of technology, biomass is attached to heavier particulate matter such as sand so the biomass can remain in the reactor vessel even against very strong hydraulic flowthrough rates. HRT in this type of reactor is measured in hours, but the need for "carrier material" can be an operational drawback. A new generation of "ultra high-rate" reactors which eliminates the need for carrier material but still retain a fluidized bed which facilitates good biomass contact, has been developed and commercialized during the past 5 years.

The use of anaerobic digestion technology to treat wastewater from industry has grown tremendously during the past decade to the point where more than 600 vendor-supplied systems are operating or under construction throughout the world. European plants comprise about $44 \%$ of the installed base, and only $14 \%$ of the systems are located in North America. A considerable number of systems are located in India and South America (primarily Brazil, where they are used to treat the vinasse coproduct from sugar cane-based ethanol production). As with farm-based anaerobic digesters, the economic advantage of recovering and using the methane-rich biogas becomes more attractive with larger systems. Given the considerable capital cost of anaerobic digesters and biogas utilization equipment designed to treat industrial wastewater, "large" systems represent a considerable percentage of the total installed base. The $230+$ large systems (those containing at least $20,000 \mathrm{~kg} / \mathrm{d}$ COD) represent more than $35 \%$ of the installed base.

\section{Acknowledgments}

This paper was prepared for the National Renewable Energy Laboratory under Subcontract CAE-3-13383-01 and was sponsored by the Regional Biomass Energy Program of the U.S. Department of Energy, Office of National Programs. Many thanks 
to the numerous persons contributing to the case studies, and especially to M.R. Hardee for editorial services.

\section{References}

1. Walsh, et al. (1988) Handbook on Biogas Utilization, Southeastern Regional Biomass Energy Program, Tennessee Valley Authority, Muscle Shoals, AL.

2. Wiltsee (1994) Heat-Activated Cooling Devices: A Guidebook for General Audiences, Southeastern Regional Biomass Energy Program, Tennessee Valley Authority, Muscle Shoals, AL.

3. Skillicorn, et al. (1993) Duckweed aquaculture: A new aquatic farming system for developing countries. The World Bank, Washington. DC.

4. Drawn from Lusk. (1994) Methane Recovery from Animal Manures: A Current Opportunities Casebook. REL/TP-421-7577, National Renewable Energy Laboratory, Golden, CO.

5. Coppinger, et al. (1980) Economics and operational experience of a full-scale anaerobic dairy manure digester. In Biogas and Alcohol Fuels Production, ed. J. Goldstein, The JG Press, Emmaus, PA.

6. Jewell et al. (1979) "Low cost methane generation on small farms," Proceedings, Third Annual Symposium on Biomass Energy Systems, Solar Energy Research Institute, Golden, CO.

7. Chandler, Hermes, and Smith (1983) "A low-cost 75-kW covered lagoon biogas system," Proceedings, Energy from Biomass and Wastes VII, Lake Buena Vista, FL.

8. Safley and Lusk (1990) Low Temperature Anaerobic Digester. North Carolina Energy Division, Raleigh, NC.

9. Oswald (1993) "Ponds in the twenty-first century," Proceedings, 2nd International Association of Water Quality Conference on Waste Stabilization Ponds and the Reuse of Pond Effluents, Oakland, CA.

10. Center for Rural Affairs. Manure Management in the European Pork Industry. August 1994 Newsletter. Walthill, NE.

11. Drawn from Sax and Lusk. (1995) Anaerobic Digestion of Municipal, Industrial, and Livestock Wastes for Energy Recovery and Disposal, Proceedings, Second Biomass Conference of the Americas, D.L. Klass, ed., National Renewable Energy Laboratory, Golden, $\mathrm{CO}$. 


\title{
ANIMAL MANURE DIGESTION SYSTEMS IN CENTRAL EUROPE
}

\author{
Erwin Köberle, Dipl.-Ing.
}

Fachverband Biogas e. V., 89611 Obermarchtat, Germany

\begin{abstract}
This work provides an overview of existing plants in Europe and describes the substrates being used. It focuses on the individual farm-scale and community plants, as these are the two main types now being built. It also describes plants currently under construction, especially in Germany and Denmark, where the major efforts are focused. A description of how the technique has developed over the past few years, its current state of development, the motivation and economic balance, and the substrate characteristics, is presented.
\end{abstract}




\section{Introduction}

There are currently about $\mathbf{4 7 0}$ biogas plants in Europe for digesting animal manure (see Table 1). An exact number is not available, as the last inquiry was made 7 years ago.

Table 1. Existing Biogas Plants in Europe

\begin{tabular}{|l|c|}
\hline Country & Approximate Number of Plants \\
\hline Germany & 200 \\
\hline Denmark & 28 \\
\hline Switzerland & 90 \\
\hline Austria & 50 \\
\hline Italy & 20 \\
\hline France & 15 \\
\hline Great Britain & 30 \\
\hline Sweden & 5 \\
\hline Other & 30 \\
\hline & 470 \\
\hline
\end{tabular}

About 150 new plants (120 of them in Germany) have been built in Europe during the past 7 years. As many as 20 plants may have been closed during this same period.

Most European plants are small- or medium-sized farm-scale plants that use $1-20 \mathrm{~m}^{3}$ substrate per day. Nine large farm-scale plants in Germany use more than $20 \mathrm{~m}^{3}$ per day. There are also several plants of this size in concentrated livestock areas of northern Italy, the Netherlands, and Denmark.

In this paper I will focus on the plants in Germany and Denmark, as biogas plant development in these countries is the most dynamic and represents the direction of the development.

\section{Current Development}

Three main types of biogas plants are currently being developed in Europe:

- Small- and medium-sized individual farm plants

- Large-scale individual farm plants (high-technology, industrially built) 
Community plants that collect manure from individual farms (high-technology, industrially built)

\section{Small- and Medium-Scale Farm Plants}

The small- and medium-sized farm plants represent about $70 \%$ of the existing plants (and about $80 \%$ of the actual annual growth). They have been in use for about 60 years, and the oldest plant (located in southern Germany) has been operating for 36 years.

Most plants in Switzerland, Austria, France, and Great Britain are small farm plants. About half of the existing 28 plants in Denmark are small- or medium-sized plants. About 190 of the plants in Germany are small- or medium-sized. Germany has seen the strongest growth of such plants during the past 2 years, with 25 new plants built during this period.

\section{Technical Achievements}

More than 100 plant designs can be distinguished in Europe. Many solutions (only a few of which have been used for series production) have been invented and constructed.

Plant building boomed in southern Germany (especially Bavaria), Switzerland, and Denmark, between 1973 and 1984. About 60 plants were built in Bavaria, 80 in Switzerland, and 10 in Denmark. Many designs (concrete or steel, vertical or horizontal) were offered by companies that emerged as biogas plants. In Germany more than 10 manufacturers, most of which had built tanks or slurry equipment, suddenly offered biogas plants. Only a few built more than one plant, and only one built more than 10 . Technical difficulties and falling oil prices forced most to withdraw from the market. Today only one company is offering medium-scale plants.

Fortunately, before and during the boom years many farmers built their own plants. With help from scientists at the agricultural school at Weihenstephan in Bavaria and from ecological groups, the farmers expertise could be gathered and disseminated.

Several engineering offices, which support farmers in building their own plants, were formed from the ecological groups. Most plants built in Germany since 1985 are based on this self-construction design, which succeeded because the technique was simplified, standardized, and combined with individual plant planning. The planning principle consists of the following parts:

- A specialized engineer performs individual planning

- The prefabricated parts are delivered as a building kit

- Local craftsmen and workers are hired

- The possibility also exists to "do-it-yourself"

Two main plant types. were developed: 
- Horizontal flowthrough steel digester, using a standard steel tank, often previously used as a gasoline tank

- Vertical steel storage digester, using a standard slurry storage tank as the digester

The horizontal steel digesters generally range from 50 to $100 \mathrm{~m}^{3}$, and occasionally to 150 $\mathrm{m}^{3}$. A stirring axle and arms reach each square foot, making this digester usable for all substrate types. Because of its limited volume and time-consuming construction, it is currently used mostly for problematic substrates such as chicken and other solid manures (see Figure 1).

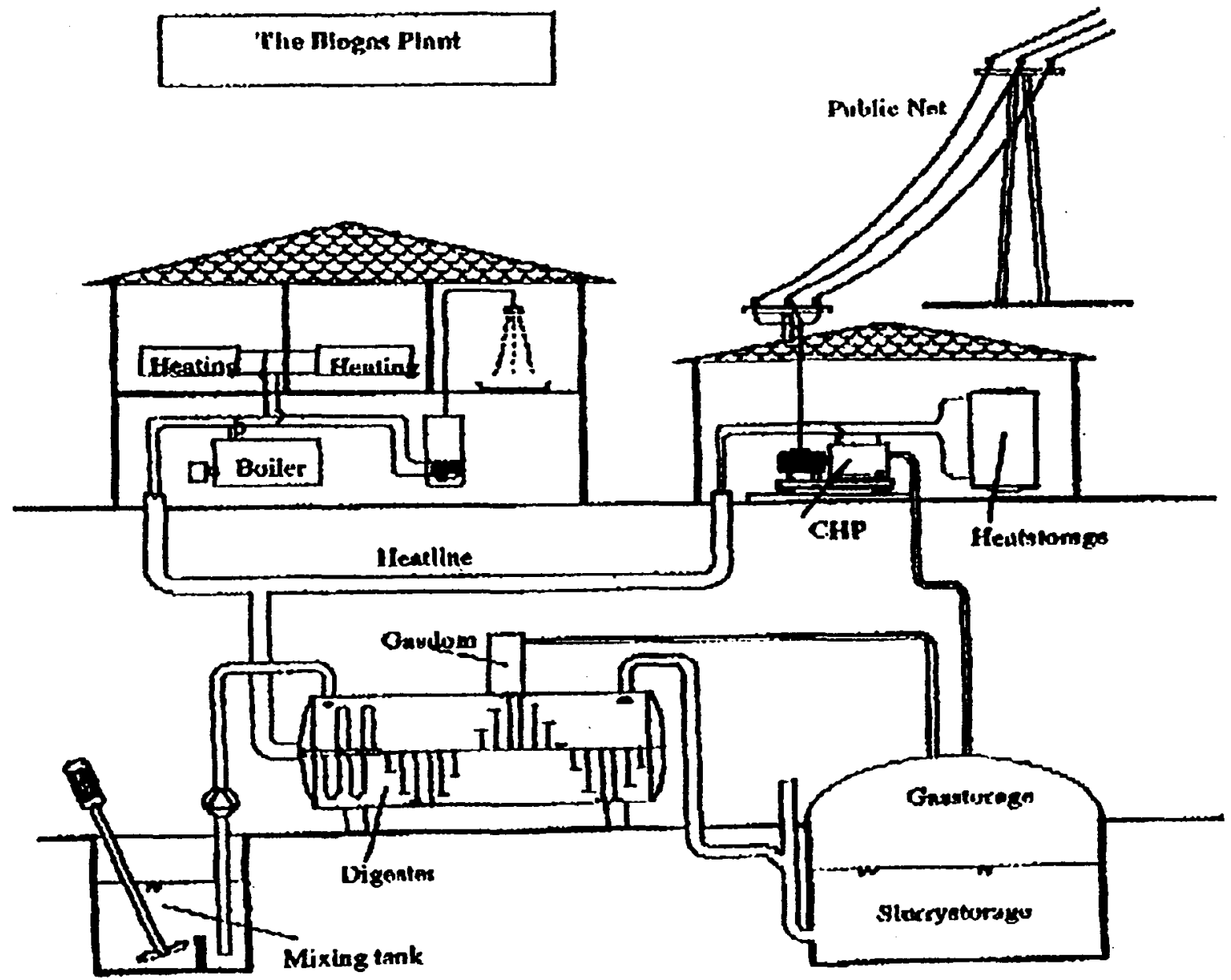

Figure 1. The biogas plant with horizontal steel digester. 
The vertical concrete digester is based on a standard concrete slurry tank as used in southern Germany. These tanks are series products that provide low-cost volume. They can be insulated and made gastight, and are often built underground, thereby reducing space demand. The volumes range from 250 to $600 \mathrm{~m}^{3}$, but some are 800 to $1200 \mathrm{~m}^{3}$ and range in depth from 3 to $6 \mathrm{~m}$ and measure 8 to $16 \mathrm{~m}$ in diameter (see Figure 2).

\section{Biogas plant in a cogorete strovartank}

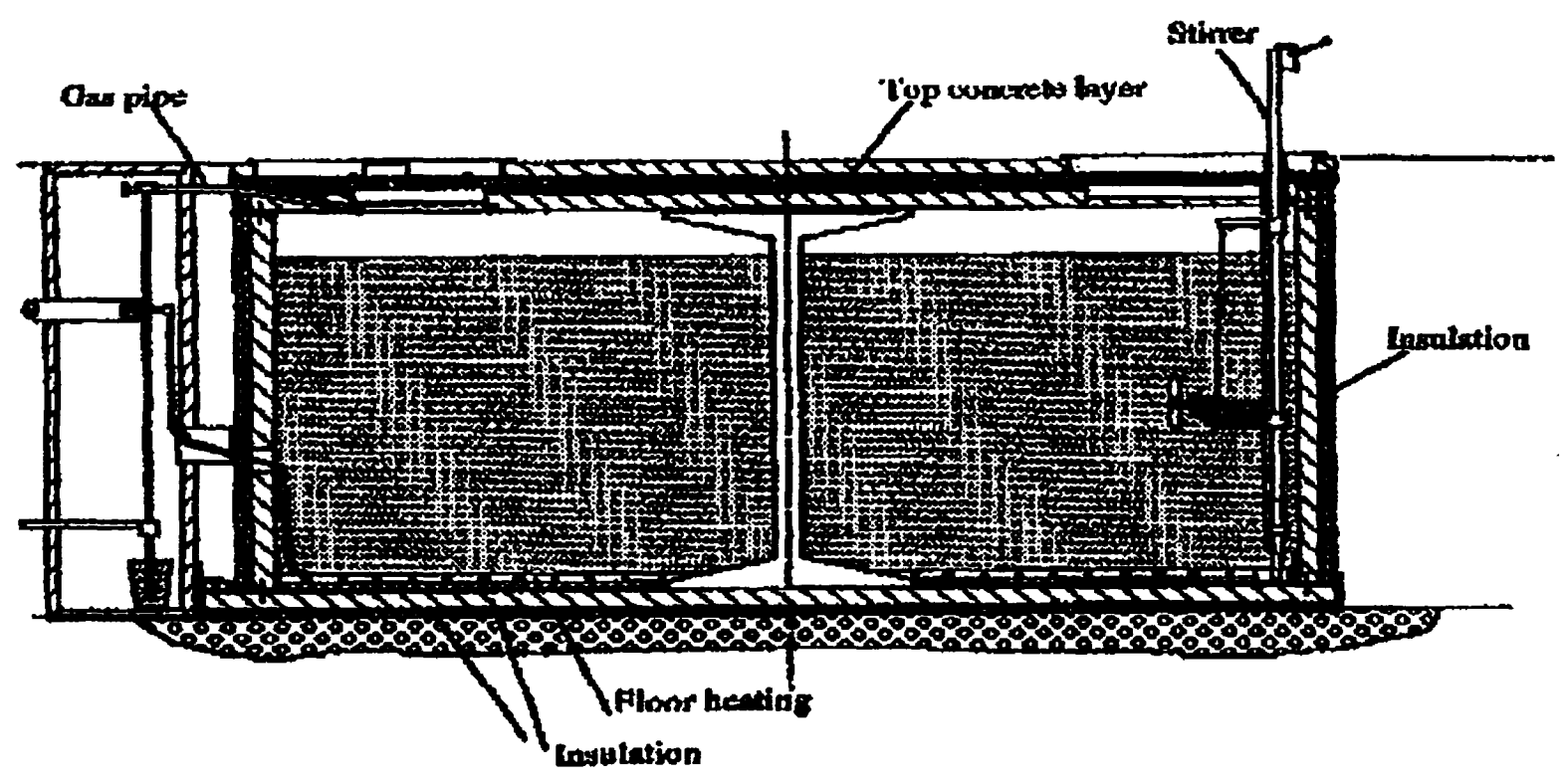

Figure 2. Vertical storage type digester

Depending on the substrate, some stirring systems also handle substrates such as solid manure with a high fiber content. Special gastight stirrers have been developed based on a standard slurry stirrer. These can be handled from the outside and adjusted to the optimum working level (see Figure 3).

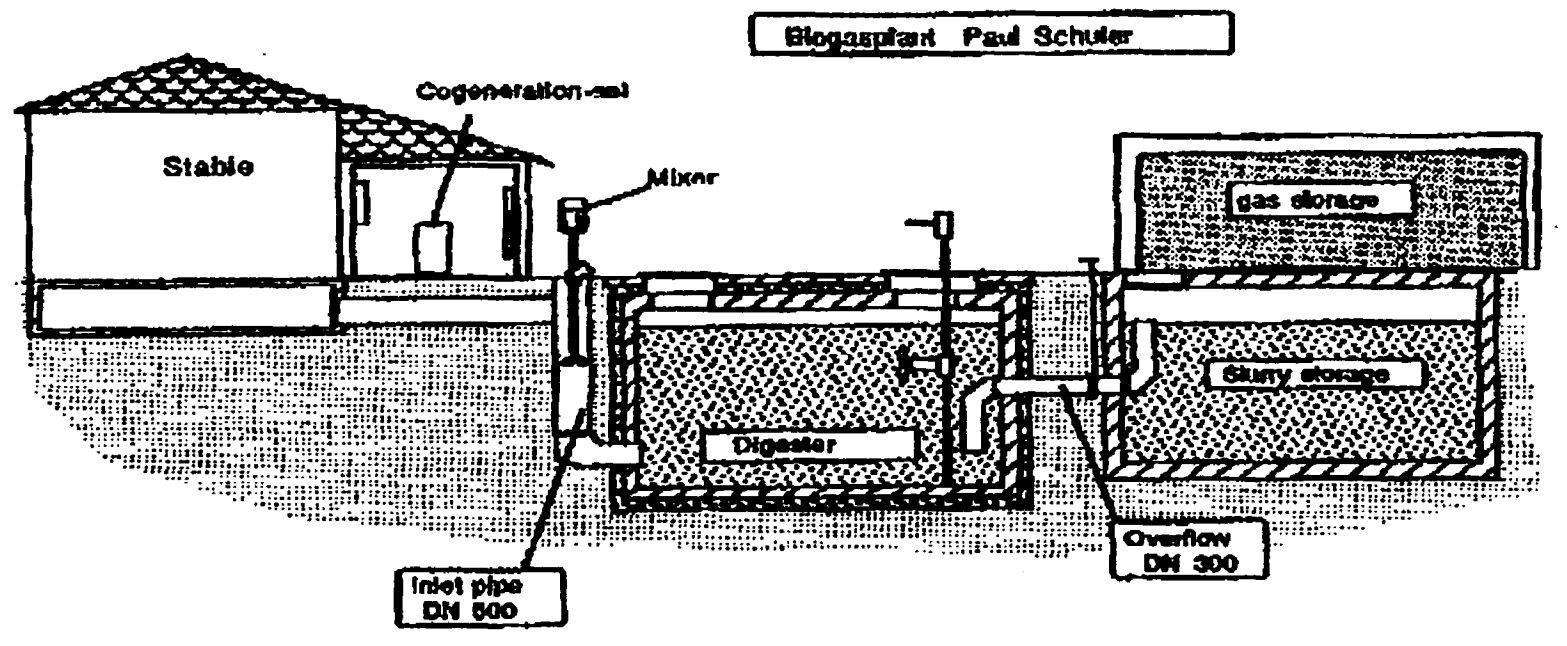

Figure 3. Small farm-scale plant, P. Schuler Wennedach 
Until 1985, most individual farm plants used gas for heating purposes only. Today most plants use it for cogeneration, with electricity as the main product and heat as a byproduct; however, it is also used to heat homes and water.

The gas is stored in balloons and protected in containers, silos, or shelter huts. The storage capacity is $60-100 \mathrm{~m}^{3}$. This biogas is stored at night, when the biogas engine is not running.

\section{Substrate Characteristics}

The main substrate is liquid slurry from cattle, pigs, and chickens. One-third of the German plants also use solid manure that includes straw and is liquefied in special mixing devices with slurry or water.

During the past 2 years, many biogas producers began adding organic matter from the food processing industry to their manure. Most types of organic waste from food processing can be used in biogas plants including wastes from slaughterhouses, oil and fat from frying, spoiled food, etc. In areas that have many biogas plants, there is already a shortage of industrial waste material.

\section{Economic Aspects}

There have been only two company-made turnkey plants built in Germany, and two in Austria, during the past 2 years. However, more than 25 self-constructed plants have been built during this same period. In Switzerland there are only company-built plants. In recent years only one or two of these have been built each year. The same applies to Denmark.

In Germany, electricity from biogas can be sold to the grid for $\$ 0.10$ (U.S.) per kWh. The gas can also be cogenerated to provide heat for the farmhouse for $\$ 2,000$ (U.S.) per year. During the summer a great deal of excess heat is lost. The cost of a selfconstructed plant for 100 cows (a typical size for southern Germany) is $\$ 100,000-\$ 120,000$ (U.S.). Subsidies are granted in most German states for biogas plants at a rate of $20 \%-25 \%$. A reasonable return on investment can be achieved under these conditions. Few company-built plants are built because they cost 50\%-100\% more than self-constructed ones.

\section{Large-Scale Farm Plants}

These plants are built by industrial contractors at large farms that have a high concentration of livestock. They use high-technology to treat and reduce the volume of slurry. During the past 5 years, five such plants have been built in Germany, and a few have been built in the Netherlands, Great Britain, and Denmark. A demonstration project was initiated to cover $50 \%$ of their costs, however, the overall costs were proven to be too high. The former Deutsche Demokratische Republik (East Germany) had seven such plants in operation, the largest of which is in Nordhausen, which produced more than $20,000 \mathrm{~m}^{3}$ of biogas per day. This plant now produces half that volume, as the volume of livestock has decreased by half. Today five plants, which depend on the cogeneration of industrial waste, still operate. 


\section{Community Plants}

Community plants use the manure from many farmers in a particular area. The first such plant began to operate 11 years ago. Today 14 plants, which use up to 80 manure deliverers and up to $\mathbf{4 4 0}$ tonnes per day of substrate, are in operation.

Community plants are especially popular in Denmark for the following reasons:

- Individual farm plants had minimal success in Denmark

- The Danish culture stresses cooperation and community involvement

- Most villages have heat distribution grids with central boilers that can make use of the waste heat produced from biogas cogeneration systems.

The first three plants were built in Jutland (in the far north) during 1986 and 1987 . At that time, numerous technical and economic problems interfered with their success. However, the Danish Energy Agency started an action program for centralized biogas plants that repaired or rebuilt existing plants and constructed new ones. Under the Agency's supervision, the builders and engineers applied lessons learned from previous constructions and tested new technologies without damaging the plants.

\section{Technical Achievements}

The manure is collected from individual farms by lorry tankers. Up to now, mesophilic digestion has been used over thermophilic digestion by a 10:5 ratio. However, four of the next five plants scheduled to be built will use thermophilic digestion.

The development of effective and cleanable heat exchangers for the slurry allows high process temperatures to be used hygienically while the plant's process heat demand remains below $20 \%$. A major task of the plant is to sanitize the substrate (eliminate pathogens), as slurry from many farms is collected and redistributed. Therefore, each plant either operates at thermophilic temperatures or includes a thermophilic step performed at $55^{\circ} \mathrm{C}$ or higher for several hours. When sewage sludge or house waste is codigested with manure, a sanitizing step performed at $70^{\circ} \mathrm{C}$ for at least 1 hour must be included.

Each of the 14 plants has a different digester design and stirring system. Some use horizontal steel cylinders or vertical steel tanks assembled by welding or bolting the concrete plates. Some plants use large, central, slow-moving stirrers; some use fastturning propellers. Some new plants use vertical steel constructions and slow-turning central stirrers. Gas may be stored in high- or medium-pressure tanks, in bell-type gasometers, in balloons, or in pressureless or double membrane systems.

The gas in most plants is cogenerated, and the heat is delivered to a municipal heating grid. The gas line can reach consumers up to $8 \mathrm{~km}$ away. Low-pressure systems have proven to be the most economical for storing and transporting gas.

\section{Substrate Source}

The substrate is the decisive element for all community plants. The first plants were constructed to use only livestock manure, but their survival depended on adding industrial 
and household waste. Today all plants depend heavily on municipal and industrial waste. Slaughterhouse waste, fish oil, frying oil, bentonite filter mass, household waste, and other food processing wastes are added in quantities up to $37 \%$ of the total input. Gas production can thus be doubled or tripled, and the process can be stabilized.

The slurry is collected from farms within a $10-\mathrm{km}$ radius of the plants by lorry tankers, which allows the area's manure to be well managed. The farms with surplus manure can send the product to farms that need more fertilizer. One of the plant staff's central tasks is to carry out the logistics of slurry transportation. The manure is stored, sanitized, homogenized, evaluated for nutrient content, and distributed to farms or fields. This enables the improved fertilizing qualities of the digested manure to be used where needed. See Table 2.

Table 2. First 10 Centralized Biogas Plants, 1994*

\begin{tabular}{|l|c|c|c|c|c|c|c|}
\hline \multicolumn{1}{|c|}{ Plant } & $\begin{array}{c}\text { Input } \\
\left(\mathrm{m}^{3} /\right. \\
\text { day) }\end{array}$ & $\begin{array}{c}\text { Manure } \\
(\%)\end{array}$ & $\begin{array}{c}\text { Organic } \\
\text { Waste } \\
(\%)\end{array}$ & $\begin{array}{c}\text { Digestion } \\
\text { Temperature } \\
\left({ }^{\circ} \mathrm{C}\right)\end{array}$ & $\begin{array}{c}\text { HRT } \\
(\text { days })\end{array}$ & $\begin{array}{c}\text { Gas } \\
\text { Production } \\
\left(\mathrm{m}^{3} / \text { day }\right)\end{array}$ & $\begin{array}{c}\text { Gas } \\
\text { Use }\end{array}$ \\
\hline \hline V. Hjermitslev & 44 & 63 & 37 & 37 & 34 & 4400 & CHP** \\
\hline Vegger & 58 & 73 & 27 & 56 & 15 & 4500 & CHP \\
\hline Skovsgärd & 53 & 70 & 30 & 35 & 29 & 3100 & CHP \\
\hline Davinde & 27 & 86 & 14 & 37 & 28 & 900 & Boiler \\
\hline Sinding & 132 & 70 & 30 & 52 & 16 & 7100 & CHP \\
\hline Fangel & 152 & 77 & 23 & 37 & 21 & 7100 & CHP \\
\hline Revninge & 37 & 75 & 25 & 44 & 15 & 1200 & $\begin{array}{l}\text { Networ } \\
k\end{array}$ \\
\hline Ribe & 401 & 84 & 16 & 53 & 12 & 11800 & CHP \\
\hline Lintrup & 385 & 67 & 33 & 37 & 20 & 11400 & CHP \\
\hline Lemvig & 453 & 79 & 21 & 52 & 17 & 14800 & CHP \\
\hline
\end{tabular}

* Progress report on the economics of centralized biogas plants, February 1995, Danish Energy Agency.

** Combined heat and power

\section{Economic Aspects}

Biogas energy in Denmark costs about $\$ 0.28$ (U.S.) per $\mathrm{m}^{3}$ when used to cogenrate combined heat and power (CHP). This stipulates a methane content of $65 \%$. Once the biogas is converted into heat and electricity, its value increases to $\$ 0.42$ (U.S.) per $\mathrm{m}^{3}$. Transporting manure and industrial waste feedstocks to centralized biogas plants 
constitutes $35 \%-50 \%$ of the plant's total operating costs. All plants own the vehicles; outside transporters are employed for most industrial wastes.

The first community plants needed a substantial subsidy $(30 \%-40 \%)$, but new plants require less than $20 \%$ ( $0 \%$ in some cases) to achieve economic balance. During the past 8 years construction has improved and prices have decreased; however, the long-term challenge for centralized biogas plants will be economic viability without industrial wastes or investment grants. Organic wastes comprise almost $90 \%$ of the substrate; already, organic wastes are being imported from Germany. Biogas plant costs must be reduced by $15 \%-20 \%$ if they are to be able to operate economically on manure alone.

\section{Individual Farm-Scale Plant in Germany (owned by Paul Schuler, Wennedach)}

Mr. Schuler's farm in Baden-Württenberg is quite typical for southern Germany. He owns 70 cows and 60 other animals, so his farm is actually somewhat larger than average at present; however, the average is expected to increase to at least his level over the next 10 years. His main income is from milk and cereals. His family (three people) are the farm's only employees. The biogas plant was built during the summer of 1994 and began operating in December (see Table 3).

Table 3. Basic Figures for the Farm-Scale Biogas Plant

\begin{tabular}{|l|l|}
\hline Daily Feedstock & $6 \mathrm{~m}^{3} / \mathrm{day}$ \\
\hline Digester Size & $475 \mathrm{~m}^{3}$ \\
\hline Digesting Temperature & $37^{\circ} \mathrm{C}$ \\
\hline Effective Digesting Volume & $425 \mathrm{~m}^{3}$ \\
\hline Stirrer & $\begin{array}{l}\text { Horizontally and vertically movable, } \\
\text { submerged propeller, } 7.5 \mathrm{~kW}, \text { gastight }\end{array}$ \\
\hline Gas Yield & $150 \mathrm{~m}^{3} /$ day $(60 \%$ methane) \\
\hline Process Heat & $25 \%$ to heat the digester \\
\hline Gas Storage & $70-\mathrm{m}^{3}$ balloon in $40^{\prime}$ container, pressureless \\
\hline Gas Cleaning & $\begin{array}{l}\text { Biocatalytic reaction in the digester by } \\
\text { adding a small quantity of air to the gas } \\
\text { zone }\end{array}$ \\
\hline Cleaning Rate & $<200 \mathrm{ppm}$ hydrogen sulfide \\
\hline Gas Use, Cogeneration & $30 \mathrm{~kW}$, dual-fuel diesel engine \\
\hline Electricity Production & $90,000 \mathrm{kWh} /$ year \\
\hline Electricity Used on the Farm & $20,000 \mathrm{kWh} /$ year \\
\hline
\end{tabular}




\begin{tabular}{|l|l|}
\hline Heat Use & $\begin{array}{l}50,000 \mathrm{kWh} / \text { year to heat the living house } \\
\left(220 \mathrm{~m}^{2}\right) \text { and provide hot water }\end{array}$ \\
\hline Investment & 150,000 Deutsche Mark* \\
\hline Subsidy & 35,000 Deutsche Mark \\
\hline $\begin{array}{l}\text { Annual Cost for Investment, Interest, and } \\
\text { Repair }\end{array}$ & 14,000 Deutsche Mark \\
\hline $\begin{array}{l}\text { Annual Income for Electricity Sale, Oil } \\
\text { Savings }\end{array}$ & 19,000 Deutsche Mark \\
\hline
\end{tabular}

1.5 Deutsche Mark = \$1 U.S.

\section{Community Plant in Denmark: Ribe}

The Ribe community biogas plant started in 1990 and is the first large-scale plant with thermophilic operation. It is owned by shareholders (the farmers that deliver the manure, a slaughterhouse, the local electricity company, and investment houses). The gas is delivered to the electricity company, which runs a cogneration set and delivers the heat to the town of Ribe (see Table 4).

Table 4. Basic Figures for the Community Biogas Plant

\begin{tabular}{|c|c|}
\hline Daily Input, Manure & 300 ton/day \\
\hline Daily Input, Industrial Waste & 40 ton/day \\
\hline Digester Size, Total & $4650 \mathrm{~m}^{3}$, three tanks of $1550 \mathrm{~m}^{3}$ \\
\hline Digesting Temperature & $53^{\circ} \mathrm{C}$ \\
\hline Effect, Digesting Volume & $4400 \mathrm{~m}^{3}$ \\
\hline Stirrer & Top-mounted, continously slowly rotating \\
\hline Gas Yield & $11,800 \mathrm{~m}^{3} /$ day ( $65 \%$ methane) \\
\hline Process Heat & $<20 \%$ to heat the digester \\
\hline Gas Storage & $\begin{array}{l}1000 \mathrm{~m}^{3} \text { balloon with double-air membrane, } \\
\text { use of iron clorin }\end{array}$ \\
\hline Investment & $\$ 7.5$ million (U.S.) \\
\hline Subsidy & $\$ 3.0$ million (U.S.) \\
\hline Sales per $\mathrm{m}^{3}$ Input & $\$ 8.20$ (U.S.) \\
\hline Costs per $\mathrm{m}^{3}$ Input & $\$ 5.20$ (U.S.) \\
\hline Income per $\mathrm{m}^{3}$ Input & $\$ 3.20$ (U.S.) \\
\hline
\end{tabular}




\section{References}

Progress Report on the Economy of Centralized Biogas Plants, February 1995, Danish Energy Agency.

Biogas-Nutzung und Potential in Europa. M. Köttner, 74592 Kirchberg, Fachverband Biogas e.V.

Wellinger, Arthur. Infoenergie, Tänikon. 


\title{
ANAEROBIC DIGESTION OF MUNICDAL SOLD WASTE: TECHNICAL DEVELOPMENTS
}

\author{
Christopher J. Rivard, Ph.D., Senior Microbiologist \\ National Renewable Energy Laboratory, Golden, CO 80401 U.S.A.
}

\begin{abstract}
The anaerobic biogasification of organic wastes generates two useful products: a mediumBtu fuel gas and a compost-quality organic residue. Although commercial-scale digestion systems are used to treat municipal sewage wastes, the disposal of solid organic wastes, including municipal solid wastes (MSW), requires a more cost-efficient process. Modern biogasification systems employ high-rate, high-solids fermentation methods to improve process efficiency and reduce capital costs. The design criteria and development stages are discussed. These systems are also compared with conventional low-solids fermentation technology.
\end{abstract}




\section{Introduction}

The anaerobic digestion process takes place through the synergistic action of four types of microorganisms: hydrolytic, fermentative, acidogenic, and methanogenic bacteria. Numerous reviews that detail the level of understanding of the anaerobic digestion process and the terminal steps of methane production have been published (1-10). The hydrolytic bacteria in these consortia use cellulase enzymes to depolymerize cellulose to simple sugars. Proteins, pectins, hemicellulose, and starches (if present in the feedstock) are also degraded enzymatically. The fermentative bacteria convert these monomers to organic acids, primarily propionic and acetic acid. The acidogenic bacteria convert these acids to hydrogen, carbon dioxide, and acetate, which the methanogens utilize via two major pathways to produce methane and carbon dioxide.

\section{Historical Commercialization}

Anaerobic digestion has been used successfully for centuries to dispose of municipal sewage (11-14). When used to treat sewage wastes, its primary purpose is to reduce the organic content, volume, odor potential, and pathogenic microorganism concentration of the sludge (11-16). Because this organic waste stream is relatively dilute, the overall effect of sewage treatment is to convert a water pollution problem into a solid waste disposal problem. However, because of the high level of water in the waste, anaerobic digestion is carried out in conventional low-solids, stirred tank reactor systems. These systems are large and require substantial energy inputs for heating and mixing. However, in treating municipal sewage, the perception of system reliability and utility often outweighs the process economics.

\section{Solid Waste Conversion}

The anaerobic digestion of lignocellulosic materials, such as biomass, agricultural residues, food processing wastes, and MSW is limited by the rate of polymer hydrolysis $(9,15)$. The primary biodegradable polymer in most biomass-cellulose -is shielded by lignin, a relatively inert, polyphenylpropane, three-dimensional polymer (16), and by hemicellulose (17). This complex structure dictates that natural biodegradation occurs over a period of months or years, rather than hours or days. Such slow rates of polymer degradation require long retention times, and large reactor volumes, which result in greater capital costs in large-scale application.

\section{Economics of Biogas Production}

Unfortunately for biogas, not all energy is created equal as described in Table 1. In general, transporation fuels of common use garner the highest value per energy unit.

This information indicates that processing costs for some fuel sources must be minimal in order to maintain profit margin. As natural gas prices are approximately one-half of petroleum and almost one-third of gasoline, the process must be maintained as low cost as possible. 
Table 1. Current Energy Value per million Btu

\begin{tabular}{|c|c|}
\hline Fuel & \$ per Million Btu \\
\hline Electricity & 20.72 \\
Gasoline & 9.33 \\
Petroleum & 7.04 \\
Natural gas (methane) & 3.79 \\
Coal & 1.47 \\
\hline
\end{tabular}

Because the methane produced is relatively low value, the anaerobic process must be rather simple in design, require little energy to operate, and produce gas at high rates. The conversion process must also result in near complete digestion to maximize energy production and residue value.

\section{Economic Criteria for Solid Waste Process Development}

When considering the anaerobic bioconversion process for solid organic wastes, we must be mindful of the economics of competing technologies for solid waste disposal. Incineration and landfilling will continue to be used (at least in the near future), with changes being made to meet more stringent environmental mandates. Similar requirements may be dictated for any disposal process, including those involving biological treatment. Biological treatments, although desirable in their natural sense of carbon cycling and co-product production (compost), are often time-consuming. Without sufficient contact time for microbial biodegradation, (especially for cellulose), incomplete digestion results, which reduces the net energy production and compost product quality. Conventional low-solids anaerobic fermentation systems have been used successfully for digesting biomass, animal manures, and MSW $(8,22,32)$. However, because of relatively slow conversion rates and long contact times, these reactor systems are large and capital intensive.

In preliminary economic evaluations of anaerobic digestion processes for producing fuel gas from solid wastes, reactor capital costs have been identified as an important cost factor. If the reactor volume could be reduced significantly and power use maintained or decreased, anaerobic digestion process economics would improve greatly. Increasing the solids concentration within the reactor would be particularly beneficial, because a decreased reactor volume is possible while the same solids loading rate and retention time are maintained. However, high-solids slurries are very viscous and resemble solid materials more closely than typical fluids. Therefore, conventional mixers such as those employed in continuous stirred tank reactor systems do not ensure homogeneity within the reactor; problems can develop in providing adequate dispersion of substrate, intermediates, and microorganisms while minimizing power requirements. 


\section{Discussion}

\section{High-Solids Digestion Systems}

High-solids anaerobic fermentations are commonly found in the landfill disposal of MSW. However, landfill high-solids anaerobic bioconversion is very slow because process control is lacking (18). High-solids anaerobic bioreactor technology development has employed a variety of designs, including non-mixed (i.e., packed bed) batch-operated reactors (generally with liquid recycle, [19-26]), and mixed or partially mixed reactor designs (27-30). In general, mixing has been viewed as a requirement for effective anaerobic fermentation for increasing the accessibility of the consortium to the substrate. In conventional low-solids systems, various agitation systems have been used successfully to anaerobically treat municipal sewage, including impeller agitators, recirculating pumps, and gas injection. However, substantial modifications of low-solids mixing systems are required to obtain mixing at high-solids levels.

The use of packed bed systems that are operated in a batch mode are enhanced through a passive mixing system that involves free liquid. These systems may approximate semicontinuous operation by using staged operation as in the SEBAC process (31). The passive mixing of solids with a pumping action is demonstrated by the bio-funnel, in which material must flow over an expanding bed (30). However, the bio-funnel requires that lower-solids materials be used to ensure a minimum level of plasticity to effectively move materials within the reactor system (i.e., $>21 \%$ ). The VALORGA system uses gas mixing to develop zones of mixing similar to low-solids "air-lift" fermentation systems. However, mixing high-solids materials with gas injection requires substantial pressures (i.e., 4-8 bar overpressure). Materials flow through the system based on a central baffle and sludge removal is enhanced by operating the reactor at slight overpressure. Mechanically mixed systems may be accomplished either through internal mixers to the reactor or alternatively by external mixing. The DRANCO system employs external mixing of the digester sludge with a smaller amount of fresh feed and reintroduces it to the unmixed reactor. In contrast, the NREL high-solids system uses a conventional internal mixer similar to a pug-mill to mix in a horizontally positioned reactor. All these designs affect in some way the fermentation efficiency, capital costs, operating and maintenance costs, and complexity of the overall process. Additionally, with at least one mixing system, (the bio-funnel), the level of solids is limited so that materials in the reactor can be effectively moved.

The mixing systems described here are representative designs for mixing high-solids materials; the list is incomplete. However, representative data from these systems are listed in Table 2 for comparison with conventional low-solids systems. This review of fermentation data has been limited to systems operated on the food/yard waste fraction of MSW. Here the MSW, obtained primarily from residential sources, has been subjected to some level of mechanical/manual separation process to remove inert (and recyclable) materials and size reduced before anaerobic digestion. 


\section{Conclusion}

The data indicate that when using a mixture of primarily food/yard wastes derived from residential MSW, organic loading rates of $15-19 \mathrm{~kg}$ volatile solids $(\mathrm{VS}) / \mathrm{m}^{3} \cdot \mathrm{d}$ may be achieved while operating the anaerobic fermentation at sludge total solids levels exceeding 30\%. The data for the high-solids systems - DRANCO, VALORGA, and NREL - are comparable with the exception of the methane yield. Potentially, by using a completely mixed system, the overall fermentation performance is enhanced in the NREL system. Additionally, differences in MSW feedstock processing may account for differences in the substrate biodegradability.

\section{Effects of High-Solids Fermentation on Reactor Sizing}

Several conclusions may be drawn about the advantages that high-solids operation affords the anaerobic process. When comparing low-solids systems to a representative high-solids system, significant advantages in relative reactor size result from reducing the level of process water, thus increasing the sludge total solids. Additionally, the high-solids system is capable of significantly higher organic loading rates, and maintains overall anaerobic bioconversion yields, that further reduce the required size of the reactor system. Combining the two effects of reducing the process water content in the reactor and increasing the organic loading rate dramatically reduces the reactor size over the conventional low-solids reactor system to treat the same volume of waste.

\section{References Cited}

1. Buswell, A. M., and Hatfield, W.D., (1936), Anaerobic Fermentations, State of Illinois Department of Registration and Education Bulletin, Chicago, 32.

2. McCarty, P.L., (1964), Public Works 95, 107.

3. Wolfe, R. S., (1971), Microbial Formation of Methane. Adv. Microbial Physiol. 6, 107-145.

4. Mah, R. A.; Ward, D. M.; Baresi, L.; Glass, T. L., (1977), Biogenesis of Methane. Ann. Rev. Microbiol. 31, 309-341.

5. Zeikus, J. G., (1977), The Biology of Methanogenic Bacteria. Bacteriol. Rev. 41, 514-541.

6. Balch, W. E., Fox, G. E., Magrum, L. J., Woese, C. R., and Wolfe, R. S. (Microbiol. Rev. 1979, 43, 260.

7. Bryant, M.P., (1979), Microbial Methane Production: Theoretical Aspects. J. Animal Sci. 48, 193-201.

8. Clausen, E. C.; Sitton, O. C.; Gaddy, J. L., (1979), Biological Production of Methane from Energy Crops. Biotech. Bioeng. 21, 1209-1219.

9. Boone, D. R., (1982), Terminal Reactions in the Anaerobic Digestion of Animal Waste. Appl. Environ. Microbiol. 43, 57-64.

10. Daniels, L.; Sparling, R.; Sprott, G. D., (1984), The Bioenergetics of Methanogenesis. Biochim. et Biophys. Acta 768, 113-163.

11. Metcalf \& Eddy, Inc., (1979), Wastewater Engineering: Treatment, Disposal, Reuse, New York: McGraw-Hill 
12. U.S. Environmental Protection Agency, (1979), Process Design Manual for Sludge Treatment and Disposal, EPA 625/1-79-011, Cincinnati, OH: Environmental Research Information.

13. Arora, M.L. (1980), Water and Sewage Works, 127, 24.

14. Federal Register, (1989), Standards for the Disposal of Sewage Sludge, Proposed Rule.

15. Noike, T.; Endo, G.; Chang, J-E.; Yaguchi, J-I.; Matsumoto, J-I., (1985), Characteristics of Carbohydrate Degradation and the Rate-Limiting Step in Anaerobic Digestion. Biotechnol. Bioeng. 27, 1482-1489.

16. Sarkanen, K.V., and Ludwig, C.H., (1971), Lignins: Occurrence, Formation, Structure, and Reactions, Wiley-Interscience, New York, NY.

17. Grohmann, K., Torget, R., Himmel, M.E., (1985) Biotech. Bioeng. Symp. 15: 59-80.

18. Rivard, C.J. "Municipal Solid Waste: The Mounting Problem". J. Environ. Health 52, 99-100 (1989).

19. Ghosh, S. "Leach-bed Two-phase Digestion- The LanFilgas Concept," in Proc. Ninth Annual Symp. on Energy From Biomass and Wastes, 743-761 (1985) January 28 - February 1.

20. Goebel, R.P. High Solids Anaerobic Digester for Rural Use, \#DE-FG03-81 SF 11613, Washington, DC: U.S. Department of Energy, 1983.

21. Hall, S.J., Hawkes, D.L., Hawkes, F.R., and Thomas, A. "Mesophilic Anaerobic Digestion of High Solids Cattle Waste in a Packed Bed Digester," J. Agric. Eng. Res. 32, 153-162, (1985).

22. Jewell, W.J. Anaerobic Fermentation of Agricultural Residue, Potential for Improvement and Implementation, US DOE Project \#DE-AC02-76ET20051, Washington, DC, 1980.

23. Lin, Y.-M. "Coupled High Solids Fermentation and Anaerobic Filtration of Cellulosic Residues," Ph.D. Thesis, Michigan State University, 1983.

24. Molnar, L., and Bartha, I. "High Solids Anaerobic Fermentation for Biogas and Compost Production," Biomass 16, 173-182 (1988).

25. Snell Environmental Group Rapid Methane Generation from Solid Waste, \#DEFG02-81R510329, Washington, DC: U.S. Department of Energy, (1983).

26. Wujcik, W.J., and Jewell, W.J. "Dry Anaerobic Fermentation," in Proc. from the Second Symp. on Biotechnology in Energy Production and Conservation, 43-65 (1979) October 3-5.

27. Begouen, O., Thiebaut, E., Pavia, A., and Peillex, J.P. "Thermophilic Anaerobic Digestion of Municipal Solid Waste by the Valorga Process," In Proc. of the Fifth Int. Symp. on Anaerobic Digestion, $789-792$ (1988) May 22-26.

28. de Baere, L., and Verstraete, W. "High Rate Anaerobic Composting with Biogas Recovery," Biocycle 25, 30-1 (1984).

29. Gaddy, J.L., and Clausen, E.C. SERI Anaerobic Digestion Program 1984 Annual Report, SERI/PR-231-2691, Golden, CO: Solar Energy Research Institute, 1985.

30. Goldberg, T., Bjergbaek, B., Djernaes, E., and Mouritzen, A. "An Anaerobic Digester for Continual High Solid Loading: The Bio-Funnel (A Radially Expanding, Overflow Digester)," in Proc. of the Int. Gas Res. Conf. 734-741 (1981).

31. O'Keefe, D.M., Chynoweth, D.P., Barkdoll, A.W., Nordstedt, R.A., Owens, J.M., and Sifontes, J., "Sequential Batch Anaerobic Composting of Municipal Solid Waste (MSW) and Yard Waste," Water Sci. Tech. 27:77-86 (1993). 
32. Isaacson, R., Pfeffer, J., Mooij, P., and Geselbracht, J., "RefCoM-Technical Status, Economics, and Market," in Klass, D., ed. Energy from Biomass and Wastes, XI, Institiute of Gas Technology, 1987.

33. Ghosh, S., "Solid-Phase Methane Fermentation of Solid Wastes," Paper presented at the 11th ASME National Waste Processing Conference, Orlando, FL, 1984.

34. De Baere, L., Van Meenan, P., Deboosere, S., and Verstraete, W., "Anaerobic Fermentation of Refuse," Resources and Conservation, 14:296-308, 1987.

35. Bonhomme, M., "The VALORGA Process for the Recycling of Urban Waste by Methanization," in Klass, D., ed., Energy from Biomass and Wastes, XII, Institute of Gas Technology, 1987.

36. Rivard, C., "Anaerobic Bioconverion of Municipal Solid Wastes Using a Novel High-Solids Reactor Design: Maximum Organic Loading Rate and Comparison with Low-Solids Reactor Systems," Appl. Biochem. Biotech., 39/40:71-82, 1993. 
Table 2. Analysis of High-Solids Reactor System Fermentation Performance with a Conventional Low-Solids System

\begin{tabular}{|c|c|c|c|c|c|c|c|}
\hline System & $\begin{array}{c}\text { Solids } \\
(\% \text { sludge })\end{array}$ & $\begin{array}{c}\text { Temp. } \\
\left({ }^{\circ} \mathrm{C}\right)\end{array}$ & $\begin{array}{c}\text { RT } \\
(\mathbf{d})\end{array}$ & Scale & $\begin{array}{c}\text { OLR } \\
\mathrm{kg} \mathrm{VS} / \mathrm{m}^{3} \cdot \mathbf{d}\end{array}$ & $\begin{array}{c}\text { CH4 Yield } \\
\text { SCM/kg VS added }\end{array}$ & Reference \\
\hline \hline CSTR & $2.7-6.3$ & 60 & $6-27$ & $2 \times 1274 \mathrm{~m}^{3}$ & $3-9.6$ & $0.13-0.30$ & 32 \\
\hline Packed Bed & $30-40$ & 35 & 90 & $0.5 \mathrm{~m}^{3}$ & 1.12 & 0.21 & 33 \\
\hline DRANCO & $30-35$ & 50 & 20 & $56.6 \mathrm{~m}^{3}$ & 16 & 0.28 & 34 \\
\hline VALORGA & 35 & 37 & 15 & $400 \mathrm{~m}^{3}$ & 15 & 0.2 & 35 \\
\hline NREL & $28-35$ & 35 & $14-20$ & $0.02 \mathrm{~m}^{3}$ & 18.5 & 0.33 & 36 \\
\hline
\end{tabular}




\title{
BIOGAS UTLIZATION
}

\author{
Mark A. Moser, MSAE \\ Resource Conservation Management, Inc. \\ P.O. Box 4715 \\ Berkeley, CA 94704 U.S.A.
}

\begin{abstract}
Options for successfully using biogas depend on project scale. Almost all biogas from anaerobic digesters must first go through a gas handling system that pressurizes, meters, and filters the biogas. Additional treatment, including hydrogen sulfide-mercaptan scrubbing, gas drying, and carbon dioxide removal may be necessary for specialized uses, but these are complex and expensive processes. Thus, they can be justified only for large-scale projects that require high-quality biogas. Small-scale projects (less than 65 cfm) generally use biogas (as produced) as a boiler fuel or for fueling internal combustion engine-generators to produce electricity. If engines or boilers are selected properly, there should be no need to remove hydrogen sulfide. Small-scale combustion turbines, steam turbines, and fuel cells are not used because of their technical complexity and high capital cost. Biogas cleanup to pipeline or transportation fuel specifications is very costly, and energy economics preclude this level of treatment.
\end{abstract}




\section{Introduction}

This paper is applicable to biogas utilization up to $90,000 \mathrm{ft}^{3}$ per day (62.5 $\mathrm{cfm}$ ), the average amount of biogas produced by $100 \%$ conversion of the manure from 1,500 dairy cows or 22,500 pigs. Biogas is produced by a digester at a steady daily rate. It is assumed that other papers have covered biogas production. This paper covers in-vessel, low-pressure (<0.5 psi) biogas storage, transmission, handling, and use.

\section{Limitations}

Because of technical complexity and high cost, medium- (up to $200 \mathrm{psi}$ ) and high-pressure ( $>2000$ psi) biogas storage will not be considered. Pressurized storage requires gas treatment to clean and dry biogas and high-pressure compressors, piping, and storage tanks. To date there is no profitable method for storing biogas at these pressures.

This paper does not cover steam generation for process steam or steam turbines, direct combustion gas turbines, Sterling engines, or fuel cells. These technologies are not currently in use at any farm digesters.

Published resources and manufacturers were consulted to verify the reasons these technologies are not in use. The excluded technologies require a greater degree of engineering, installation, and operating skills than normally found in the farm community. Small-scale equipment is custom built and supplied by a very limited group of suppliers. Service for these units is generally unavailable.

A more detailed discussion of equipment can be found in Biogas Utilization Handbook published by the U.S. Department of Energy, Southeastern Regional Biomass Energy Program, Tennessee Valley Authority, Muscle Shoals, Alabama 35660. Individual equipment suppliers should be contracted for equipment performance and specifications.

\section{Biogas Utilization Considerations}

\section{Location}

Energy utilization equipment should be protected from animals and machinery in an area of the farm frequented by farm personnel. All buildings and equipment should be installed with adequate room for servicing and in accordance with all building codes. Short distances for transmitting biogas and hot water through buried pipes are preferable.

\section{Safety Considerations for Biogas}

The major components of biogas are methane $\left(\mathrm{CH}_{4}\right)$ and carbon dioxide $\left(\mathrm{CO}_{2}\right)$. Another component of concern is hydrogen sulfide $\left(\mathrm{H}_{2} \mathrm{~S}\right)$. Biogas such as "manure gas" can be toxic if inhaled directly, corrosive to equipment, and potentially explosive in confined space when mixed with air. When properly managed, biogas is as safe as any other fuel such as propane used on the farm. If improperly managed, these elements can be very hazardous, as shown by the number of "manure gas" incidents in which farmers have been injured or killed (see Appendix). 


\section{iystem Safety}

3uried pipes should be placed adjacent to, but not in, roadways to avoid crushing. Aboveground plastic pipe should be placed where it cannot be frozen or damaged. Fencing or impact barrier posts may be needed. The very low pressure $(<1 \mathrm{psi})$ of biogas $\mathrm{n}$ the piping system limits risks associated with damaged piping. Because of the potential or accumulation of gases, biogas equipment should be installed in properly ventilated ooms with adequate air inlet and exhaust. Exhaust stacks, flares, or emergency gas oressure relief valves should be located away from buildings and ventilation intakes, and should be placed high enough to avoid danger to people and livestock. "Confined space entry," "no smoking," and "fire hazard" signs should be posed where necessary. A simple gas detection monitor and alarm are recommended.

\section{Biogas Production}

Daily biogas production, with storage limited to less than 12 hours of production, is the key factor in sizing all system components.

\section{Biogas Flow Rate}

The maximum biogas flow rate $\left(\mathrm{ft}^{3} / \mathrm{min}\right)$ with a 1.5 safety factor should be used to size all components.

\section{Selection of Materials}

All materials, such as PVC, ceramic, stainless steel, or aluminum, should be corrosion resistant. Carbon-steel should be painted with multiple coats of an epoxy paint (or equivalent) to reduce corrosion.

\section{Value of Energy}

By far the most important issue in biogas use is the value of the energy replaced by biogas.

\section{Heat Recovery for Digester}

If heat recovery for digester heating is required, it must be considered throughout a design process.

\section{Biogas Transmission}

Biogas must be conveyed via a transmission system from the digester to the gas handling system.

\section{Components}

\section{Low-Pressure Storage}

The digester cover system may be designed to store a small amount of biogas for a short time. Floating or inflatable covers may be used to store 1 to 12 hours of biogas production at pressures less than 2 inches water column pressure $(.07 \mathrm{psi})$. Properly designed fixed covers may be able to store 1-3 hours of gas production at up to 10 inches water column pressure (.37 psi) depending on the head space available below the cover. 


\section{Biogas Intake}

The biogas intake is a pipe (usually PVC) extending under the biogas collection cover and into the gas space to collect biogas and withdraw it to the biogas transmission system. A minimum 6 inches intake should be used to reduce clogging.

\section{Gas Pressure Relief}

A pressure relief value releases pressure buildup when biogas is produced faster than it is being used, and should release excess biogas in a pipe to a flare. Commercial pressure relief valves are available, or simple manometer-type pressure reliefs can be built.

\section{Flame Arrester (optional)}

A flame arrester prevents flame from burning back down a pipe. This is not expected to be needed, because there is no oxygen in the gas to allow combustion. Some local building codes may require a flame arrester. Commercial flame arresters are available, or simple small arresters can be built.

\section{Condensate Drain}

Biogas, as produced, is saturated with water vapor. When biogas exits the digester and enters the pipeline, water vapor condenses on the cooler surfaces and must be drained from the pipe. At least one condensate drain is needed. Simple "J" or "U" traps below $T$ fittings are suitable condensate drains that require little or no maintenance. An access sump or manhole may be required for observation and service. Additional condensate drains will be required at all low points in a biogas transmission pipe. Condensate drain manholes should not be located where surface water or groundwater can enter the manhole, because water may backflow from the manhole into the biogas transmission pipe and cut off gas flow.

\section{Flare}

A flare is recommended to burn off excess biogas. There may be occasional excess biogas production or times when the gas use system is under repair and excess gas must be released. Flaring will reduce potential dangers associated with unburned biogas. Commercially available flares or farm-built flares may be used. A windscreen prevents flare blowout. A farm-built flare can be constructed from excess construction materials in about 4 man-hours. Automatic ignitors should be resistant to corrosive gases.

\section{Transmission Pipe}

PVC pipe is commonly used to transmit biogas from the methane recovery system to the utilization system. Underground transmission pipe is sloped to a condensate drain. If installed aboveground, PVC must be painted and protected from breakage. Some city or county codes may require exposed biogas piping to be metal.

\section{Biogas Handling}

To properly size components, the gas use must be identified before the biogas handling system is developed. The biogas transmission system is designed to deliver biogas at a pressure between 0.5 and 8 inches of water column, depending on the collection cover system. 


\section{Components}

\section{Gas Filter}

All gas streams should have an inline " $Y$ " type strainer-screen filter as a minimum to zatch debris left in the pipeline during construction.

\section{Gas Treatment (optional)}

Biogas is saturated with water vapor and will contain $\mathrm{H}_{2} \mathrm{~S}$. Table 1 shows ranges of $\mathrm{H}_{2} \mathrm{~S}$ found in biogas streams. Properly operated engines and boilers will not require gas reatment. Gas treatment may be needed for gas uses where hydrogen sulfide could be zorrosive to equipment such as combustion turbines, direct fire room heaters, adsorption shillers, and forced air furnaces.

For small-scale biogas uses, the most cost-effective biogas treatment technique is dry shemical oxidation to bind sulfur compounds. Iron sponge, activated carbon, and shemically impregnated filter cartridges can be used to remove in line debris, water vapor, or $\mathrm{H}_{2} \mathrm{~S}$. The filter should be sized to have a maximum pressure drop between 0.5 to 1 inch when new and a 6 to 12-month filter material service life.

Table 1. Ranges of Hydrogen Sulfide Found in Biogas from Various Sources

\begin{tabular}{lc}
\multicolumn{1}{c}{ Digester Type } & Range of $\mathrm{H}_{2} \mathrm{~S}$ in Biogas \\
\hline Covered Lagoon & $500-2500 \mathrm{ppm}$ \\
Complete Mix Digester & $1800-6000 \mathrm{ppm}$ \\
Plug Flow Digester & $1500-2800 \mathrm{ppm}$
\end{tabular}

\section{Gas Pump or Blower}

A gas blower or pump is used to increase biogas pressure up to $10 \mathrm{psi}$. The gas blower/pump can be either a vane or lobe type and either belt or direct driven. The gas blower should be made of noncorrosive materials and have a noncorrosive shaft seal.

\section{Gas Meter}

An accumulator-type flow-through gas meter with a readable face is used to measure biogas flow to the gas use. A lobe or vane meter is preferred. A bellows-type natural gas meter should not be used. Meter components that contact biogas should be stainless steel. The daily gas quantity is used to monitor and infer the biological health of the methane recovery system. The ratio of a daily output ( $\mathrm{kWh}$, tons of cooling, Btu of heat) to daily gas quantity is monitored to assess the status of the equipment.

\section{Gas Backpressure Regulator (optional)}

A commercial backpressure regulator is used to relieve excess gas pressure back to the beginning of the gas handling system.

\section{Condensate Drain}

Condensate drains are required at all low points. 


\section{Biogas Use}

Biogas that is pressurized and metered can be used as fuel for heating, adsorption cooling, electrical generation, and cogeneration. Biogas can be substituted for low-pressure natural gas or propane in the equipment listed in Table 2. Many other types of equipment are possible. Only those currently in use will be further described.

\section{Table 2. Common Biogas Use Options}

\section{Biogas Fueled Engine}

Electrical generator-electricity for use or sale, heat recovery optional

\section{Direct Combustion Options}

Hot water boiler-for space heat, process and cleanup hot water

Demonstrated but not in use-direct fire heaters, adsorption chillers

\section{System Operation Plan}

A system operating plan must be developed to determine how to use the biogas. Tables 3 and 4 list important factors in developing a biogas use option.

Table 3. Important Factors-Biogas Supply

1) Biogas is produced year-round

2) Biogas storage for longer than $23 \mathrm{~h}$ is very expensive

3) Biogas production from heated complete mix and plug flow digesters should be stable, if manure collection is stable

4) Biogas production from covered lagoon digesters will vary seasonally

5) Digester may require heat

\section{Table 4. Important Factors-Biogas Use}

1) Space heat and cooling requirements vary seasonally

2) Product refrigeration requirements are usually continuous, though total requirements vary seasonally

3) Electricity use may be widely variable daily and seasonally

4) Electricity use varies between farms and management techniques

5) Adsorption chillers and engine-driven uses can recover hot water

6) Digester may require heat 


\section{Selecting and Sizing Biogas Use Options}

Biogas use must be matched to biogas availability and energy requirements. The most appropriate use for biogas is to replace purchased energy for heating, cooling, or electricity. A gas use should be selected to maximize economic return. The price, quantity, and pattern of electrical and thermal energy consumption must be analyzed to assess potential project returns. An electricity cost in 1995 of $\$ 0.065$ per $\mathbf{k W h}$ or a propane value of $\$ 0.70 /$ gallon are probably the minimum values at which biogas substitution can be feasible.

\section{Biogas Requirement of Gas Use Equipment}

Table 5 summarizes the estimated Btu requirements of various biogas use options.

Table 5. Equipment Biogas-Btu Use Estimates (estimation purposes only)

Assumes biogas is $600-750 \mathrm{Btu} / \mathrm{ft}^{3}$

Biogas Fueled Engine at $23.5 \%$ efficiency

Engine-driven generator-15,000 biogas $\mathrm{Btu} / \mathrm{kWh}$

\section{Direct Combustion Options}

Hot water boiler-Natural gas Btu requirement $\times 110 \%$

Direct fire room heater-Natural gas Btu requirement $\times 110 \%$

Adsorption cooling-3-30 ton/h standard - 27,500 biogas $\mathrm{Btu} / \mathrm{h} / \mathrm{ton}$ cooling

$30+$ ton/h double effect $-13,400$ biogas $\mathrm{Btu} / \mathrm{h} /$ ton cooling

\section{Biogas Fueled Internal Combustion (IC) Engines}

The most common use of biogas on a farm is to fuel an engine generator to produce electricity for on-farm use or off-farm sale. Hot water for digester heating and on-farm uses can be recovered from the engine jacket water and exhaust. Hot air has been recovered from radiator exhaust to heat buildings.

Natural gas or propane engines are easily converted to burn treated biogas by modifying carburetion and ignition systems. Natural gas engines are available in virtually any capacity. The most successful engines are industrial natural gas engines that can burn untreated biogas. A biogas fueled engine-generator will normally convert $18 \%-25 \%$ of the biogas Btu to electricity, depending on engine design and load factor. Gas treatment is not necessary if proper maintenance procedures are followed. Biogas engines less than 200 horsepower $(150 \mathrm{~kW})$ generally meet all California air pollution restrictions without modification if run with a lean fuel mixture. 
Control systems for engine-generators are well developed. The control system must operate in the harsh environment of a farm, and excess automation often fails-where simple manual and mechanical controls usually succeed.

\section{Electricity Generation Options}

\section{Isolated versus Parallel Power Production}

A farm may choose to use a stand-alone engine-generator to provide all or part of its own electricity as an "isolated" system or operate connected to and mixing electricity with the utility "in parallel."

An isolated system must be able to function continuously, without interruption, to meet fluctuating levels of electricity demand while maintaining a smooth and steady 60-cycle current. Varying electrical loads or large motor starting loads can lead to drift in the 60cycle current. Drift results in wear on motors, speedup or slowdown of clocks and timers, and operating problems with computers and programmable logic controllers.

Isolated systems require a sophisticated control system and a gas reservoir to meet changing loads. They are generally oversized to accommodate the highest electrical demand, but operate less efficiently at average or partial load.

A parallel system is directly connected to the utility and matches the utility phasing, frequency, and voltage so that farm-produced power blends directly with utility line power. A utility intertie panel with safety relays is required to operate in parallel and to disconnect the farm generator if there is a problem with either the utility or the farm generation.

Parallel operation allows the farm generator to run at a constant output regardless of farm demand. Constant output allows more efficient use of biogas and less wear on the engine. The engine-generator can be sized for biogas availability rather than for farm requirements. The farm buys power when it underproduces and sells power when it overproduces. The utility is the system backup if engine maintenance is required.

\section{Generator Options}

\section{Induction Generators versus Synchronous Generators}

A synchronous generator will operate either isolated or in parallel. It can provide electricity to the farm if the utility is shut down. Synchronous parallel generation requires a sophisticated intertie to match generator output to utility phase frequency and voltage.

An induction generator will operate in parallel with the utility and cannot stand alone. Induction generation derives its phase, frequency, and voltage from the utility. Fewer, less-sophisticated relays are required to protect the utility. Negotiations with a utility for intertie of a small induction generator are generally much easier. 


\section{Parallel Operating Schemes}

\section{Generation for On-Farm Use and Surplus Sale}

The goal is to produce primarily to avoid purchasing electricity from the utility. Shortages are purchased and excess is sold.

\section{Sale of Electricity to the Utility}

The goal is to produce and sell electricity to the utility. Also known as "buy-sell" agreement, the utility pays for all electricity produced and the farm pays for all electricity used. Most utilities currently buy electricity for approximately $25 \%$ of the sale price.

\section{Preferred Operation Scheme}

An ideal agreement would be a monthly offset of excess kilowatts sold off-farm against any power purchased on-farm with appropriate payment or credit.

\section{Utility Issues}

The key issue in developing a profitable biogas recovery system is the value of the energy to the owner. A careful review of utility rates and interconnection requirements is necessary before selecting the operating mode. Rate negotiation is appropriate for farmscale projects, as most rules are set up for very large independent power producers.

\section{Effects of Utility Rate Structures}

The farm has to be careful in rate analysis because high "demand" charges can negate half the value of the electricity produced. "Demand" is usually the highest rate of electricity consumption for $\mathbf{1 5}$ minutes during a month. To offset demand charges, a generator must achieve $99.95 \%$ operation. Some utilities offer a "backup" or "standby" charge, which is usually lower than a demand charge.

Under Section 210 of the Federal Public Utility Regulatory Policies Act of 1978 (PURPA), utilities must purchase power produced by qualifying cogenerators and small power producers. Biogas-fueled electricity generation qualified by definition. However, the utilities seldom offer reasonable purchase prices. If electricity can be sold more profitably to a neighboring facility, this option can be investigated.

\section{Intertie Requirements}

Each utility has intertie requirements for protective relays to disconnect the generator automatically if the power line near the farm is accidentally broken or if there is a problem with the generator. These relays are necessary to protect farm and utility personnel. A professional familiar with intertie equipment should negotiate with the utility and supply the appropriate gear. Negotiation is necessary because of the potential cost of the intertie. Solid-state relays and electromechanical relays perform the same function; however, electromechanical relays may cost 10 times more. A utility may need high-cost relays for very large power producers, but lower-cost relays operate well for farm-scale installations. 
Thousands of biogás-fired boilers are in use at municipal waste treatment plants in the U.S., where they provide hot water for building and digester heat. Conversion efficiencies are typically $75 \%-85 \%$. Several have been installed on farm digesters. Farms require hot water year-round, but there is typically more biogas available than hot water required. Farrow to wean and farrow to nursery hog farms in cold climates are the only types of farm where hot water use could consume most or all of the available biogas production potential.

A cast iron natural gas boiler can be used for most farm applications. The air fuel mix will require adjustment, and burner jets will have to be enlarged for low Btu gas. Cast iron boilers are available in a wide range of sizes from $45,000 \mathrm{Btu} / \mathrm{h}$ and larger. Untreated biogas can be burned in these boilers; however, all metal surfaces of the housing should be painted. Flame tube boilers with heavy gauge flame tubes may be used if the exhaust temperature is maintained above $300^{\circ} \mathrm{F}$ to minimize condensation. High $\mathrm{H}_{2} \mathrm{~S}$ concentration in the gas may clog flame tubes.

\section{Future Alternatives-Forced Air Furnaces, Direct-Fire Room Heaters, Adsorption Chillers}

Forced air furnaces, direct-fire room heaters, and adsorption chillers fueled by treated biogas have been demonstrated but are not commonly used in the U.S. This equipment is manufactured from thin metal and is not corrosion resistant; therefore, gas treatment for water and $\mathrm{H}_{2} \mathrm{~S}$ removal is needed. Also, these units must be rejetted with larger burner orifices. These technologies are most suited to covered lagoon digester gas production because they are generally not designed to return hot water necessary for digester heating. However, most facilities do not need either heating or cooling yearround.

Forced air furnaces could be used on hog farms in place of direct-fire room heaters. Direct-fire room heaters are commonly used in hog farrowing and nursery rooms. A farm will typically have multiple units. Biogas-fired units have not been installed in the U.S. because owners are reluctant to risk losses in animal production. These heaters are available and in use in Taiwan.

Gas-fired adsorption chillers produce cold water for milk cooling or air conditioning. Dairies cool milk every day of the year. Chilled water or glycol can be used in milk precoolers in place of well water. Units are under development that should produce glycol at temperatures lower than $30^{\circ} \mathrm{F}$ and allow direct refrigeration. A dairy generally requires 0.014 tons of cooling per hour per milk cow per day, which is about $15 \%$ of the potential biogas production from the same cow (one ton cooling $=12,000 \mathrm{Btu} / \mathrm{h}$ ).

Double effect chillers, producing hot and cold water simultaneously, are available for applications more than 30 tons and could be coupled with a heated digester. 


\section{Appendix \\ Safety Concerns of Biogas Components}

\section{Methane}

Potential hazards: asphyxiation, explosion. When collected from a digester, methane makes up $60 \%-80 \%$ of the biogas volume. As generated and collected, biogas does not contain oxygen. As collected, there is no combustion or explosion hazard due to the lack of oxygen. The piped biogas will not burn until mixed with air. Methane generally does not collect in pits as it is lighter than air. If released in a confined space and diluted to approximately $17 \%-23 \%$ concentration in air and given a source of ignition, an explosion can occur. If it leaks into a sealed or poorly ventilated room and displaces air, the lack of oxygen can be harmful to animals and humans. Smoking should be prohibited in areas where biogas is collected and used.

\section{Carbon Dioxide}

Potential hazards: asphyxiation. $\mathrm{CO}_{2}$ makes up $20 \%-40 \%$ of the biogas volume, is heavier than air, and will collect in poorly ventilated pits and confined spaces, while other gases dissipate. $\mathrm{CO}_{2}$ does not burn or explode. If it leaks into a sealed or poorly ventilated room and displaces air, the lack of oxygen can be harmful to animals and humans. Entry into pits or confined spaces filled with $\mathrm{CO}_{2}$ may result in asphyxiation.

\section{Hydrogen Sulfide}

Potential hazards: human toxicity, equipment corrosion. $\mathrm{H}_{2} \mathrm{~S}$ is present in the air of all confined animal feeding operations. It is lighter than air and dissipates rapidly. Very low concentrations corrode steel, iron, aluminum, and copper. $\mathrm{H}_{2} \mathrm{~S}$ makes up $0.1 \%-0.3 \%$ (500 $\mathrm{ppm}$ to $6000 \mathrm{ppm}$ ) of the volume. $\mathrm{H}_{2} \mathrm{~S}$ can be detected by its "rotten egg" smell in concentrations of $1-100 \mathrm{ppm}$. Direct inhalation of $\mathrm{H}_{2} \mathrm{~S}$ in concentrations above $10 \mathrm{ppm}$ is harmful to the respiratory tract. Direct inhalation of $\mathrm{H}_{2} \mathrm{~S}$ above $500 \mathrm{ppm}$ will cause rapid respiratory failure, and inhalation of concentrations above $1000 \mathrm{ppm}$ can cause unconsciousness and death. 


\title{
ENVIRONMENTAL IMPACTS OF ANAEROBIC DIGESTION AND THE USE OF ANAEROBIC RESIDUES AS SOIL AMENDMENT
}

\author{
Frank E. Mosey BSc, Environmental Consultant, \\ VFA Services Ltd, 32 Park View, Stevenage, \\ Herts, SG2 8PS, United Kingdom
}

\begin{abstract}
This paper defines the environmental role of anaerobic digestion within the overall objective of recovering energy from renewable biomass resources. Examples and opportunities for incorporating anaerobic digestion into biomass-to-energy schemes are discussed, together with environmental aspects of anaerobic digestion plants. These include visual, public amenity, pathogens and public health, odor control, and gaseous emissions. Digestate disposal and the benefits of restrictions on recycling organic wastes and biomass residues back to the land are discussed, particularly as they relate to American and European codes of practice and environmental legislation. The paper concludes that anaerobic digestion, if performed in purpose-designed reactors that efficiently recover and use biogas, is an environmentally benign process that can enhance energy recovery and aid the beneficial land use of plant residues in many biomass-toenergy schemes.
\end{abstract}




\section{Introduction}

Anaerobic digestion (methanogenesis) is a natural bacterial process during which organic matter is fermented to produce a biogas, which typically contains about $60 \% \mathrm{CH}_{4}$ and $40 \% \mathrm{CO}_{2}$. It occurs wherever wet organic matter accumulates in the absence of air, in the sediments of oceans and lakes, in wetlands and rice paddies, and within the digestive tracts of many animals, especially termites and ruminants. It is an environmentally benign process that benefits mankind by removing putrescible waste materials, destroying odors and pathogens, and recycling plant nutrients and humus solids to improve soil fertility. The $\mathrm{CH}_{4}$ it produces is somewhat of a mixed blessing. Released directly to atmosphere it is a powerful greenhouse gas. Captured and burned to $\mathrm{CO}_{2}$ and water, it provides a useful renewable fuel.

\section{Anaerobic Digestion for Renewable Energy Production}

Pure methane has a gross calorific value of $39.7 \mathrm{MJ} / \mathrm{m}^{3}$, and the biogas produced by the anaerobic digestion process has a gross calorific value of $23.8 \mathrm{MJ} / \mathrm{m}^{3}\left(640 \mathrm{Btu} / \mathrm{ft}^{3}\right)$, which makes it a useful renewable fuel for generating electricity or steam. The gas bubbles directly from the fermentation vessel and can be collected without any sophisticated extraction procedure. Even after deducting the electricity required to operate plant machinery, anaerobic digesters are net energy producers and offer an efficient method of capturing residual energy values from wastes and by-products that are too wet or otherwise unsuitable for incineration. The major energy requirement of the process is low-grade heat to warm the fermentation tank (to $35^{\circ} \mathrm{C}$ or $55^{\circ} \mathrm{C}$, as appropriate).

\section{Biogas, M̄ethane, and Energy Yields}

Methanogenic fermentations generate very little metabolic heat and, as shown in Table 1 , complete quantitative transfer of calorific values to methane is theoretically possible.

Table 1. Theoretical Biogas, Methane, and Energy Yields from Anaerobic Digestion of Pure Compounds (per kg Organic Matter Destroyed).

\begin{tabular}{|l|l|c|c|c|}
\hline $\begin{array}{l}\text { Pure } \\
\text { Compounds }\end{array}$ & $\begin{array}{c}\text { Calorific } \\
\text { Value } \\
(\mathrm{MJ} / \mathrm{kg})\end{array}$ & $\begin{array}{c}\text { Biogas Yield } \\
(\mathrm{m} 3 / \mathrm{kg})\end{array}$ & $\begin{array}{c}\text { Methane } \\
\text { Yield (m3/kg) }\end{array}$ & $\begin{array}{c}\text { Calorific Value } \\
\text { of Methane* }\end{array}$ \\
\hline Fats & $38,200^{* *}$ & 1.44 & 1.03 & $40,900 \mathrm{MJ}$ \\
Proteins & $17,400^{* *}$ & 0.96 & 0.51 & $20,200 \mathrm{MJ}$ \\
Carbohydrates & $16,000^{* *}$ & 0.79 & 0.39 & $15,500 \mathrm{MJ}$ \\
\hline Acetic Acid & 14,600 & 0.75 & 0.37 & $14,700 \mathrm{MJ}$ \\
Ethanol & 29,000 & 0.97 & 0.73 & $29,000 \mathrm{MJ}$ \\
Glycerol & 18,000 & 0.73 & 0.43 & $17,100 \mathrm{MJ}$ \\
\hline
\end{tabular}

* Gross CV per $\mathrm{kg}$ of substrate converted to methane

** Varies slightly according to its precise composition 
In practice, even $100 \%$ biodegradable substrates are only $75 \%-85 \%$ converted to biogas. The remainder appears as new microbial biomass in the final digestate product. Even so, potential conversion efficiencies remain high and anaerobic digestion is an efficient way of recovering energy values from biodegradable materials.

\section{Lignin, Cellulose, and the Limits of Biodegradability}

Up to $30 \%$ lignin may be present in woody plants. Its purpose is to protect the plant from microbial decay. Lignin is completely nonbiodegradable in anaerobic environments, and even its aerobic degradation is slow and limited to a few species of soil bacteria and fungi. Pure cellulose is readily fermented in anaerobic digesters, but its natural forms are often protected from biodegradation by their lignin content. For example, hay, straw, alfalfa, and bagasse are $40 \%-70 \%$ degradable in the rumen and in anaerobic digesters, but sawdust and coconut fiber are virtually inert to anaerobic digestion (Huub et al. 1988). Processed woody biomass (paper and board) also varies greatly in its anaerobic biodegradability.

\section{Biogas from Biowastes}

The traditional role of anaerobic digestion is to stabilize, deodorize, and disinfect biodegradable waste materials for disposal. Here the energy is generally regarded as a by-product of the waste stabilization. Examples include:

\section{Anaerobic Digestion of Sewage Sludges}

Anaerobíc digestion was first developed as an engineered process to deodorize and disinfect sewage sludges, and is widely used to allow wastewater treatment utilities to spread their sludges onto farmland and improve soil fertility without creating a public nuisance or a human health hazard. The process is traditionally undertaken by fermenting dilute (3\%-6\%DS) slurries at $35^{\circ} \mathrm{C}$ in completely mixed cylindrical concrete tanks. At larger installations, biogas from the digesters is used to fuel gas engines to generate electricity. The largest installation in the UK is at Becton STW (serving northeast London), where the biogas is used to fuel gas turbines that generate $7.8 \mathrm{MW}$ of electricity. The most sophisticated sludge-to-energy recovery plant in the world is at the Hyperion Sewage Treatment Plant (serving the city of Los Angeles, California), which includes a gas turbine combined cycle power train that generates $12.6 \mathrm{MW}$ of electricity from sludge digester gas (Makansi 1984). Smaller installations generally use sparkignition or dual-fuel (biogas/oil) CHP gas engines to generate electricity, with waste heat from the engine jacket cooling water being used to heat the digestion tanks.

\section{Anaerobic Digestion of Farm Livestock Wastes}

The same technology has also been used to treat animal slurries from intensive livestock farms. For individual farms, these tend to be "low-tech" construction with the digestion tank set in the ground for minimal visual intrusion and improved thermal insulation. U.S. farm practices tend to produce dilute $(1 \%-2 \% \mathrm{DS})$ slurries and to favor covered lagoons. European farm practices tend to produce smaller volumes of thicker (4\%-8\%DS) slurries that can permit thermophilic $\left(55^{\circ} \mathrm{C}\right)$ operation. In Denmark, individual farmers form 


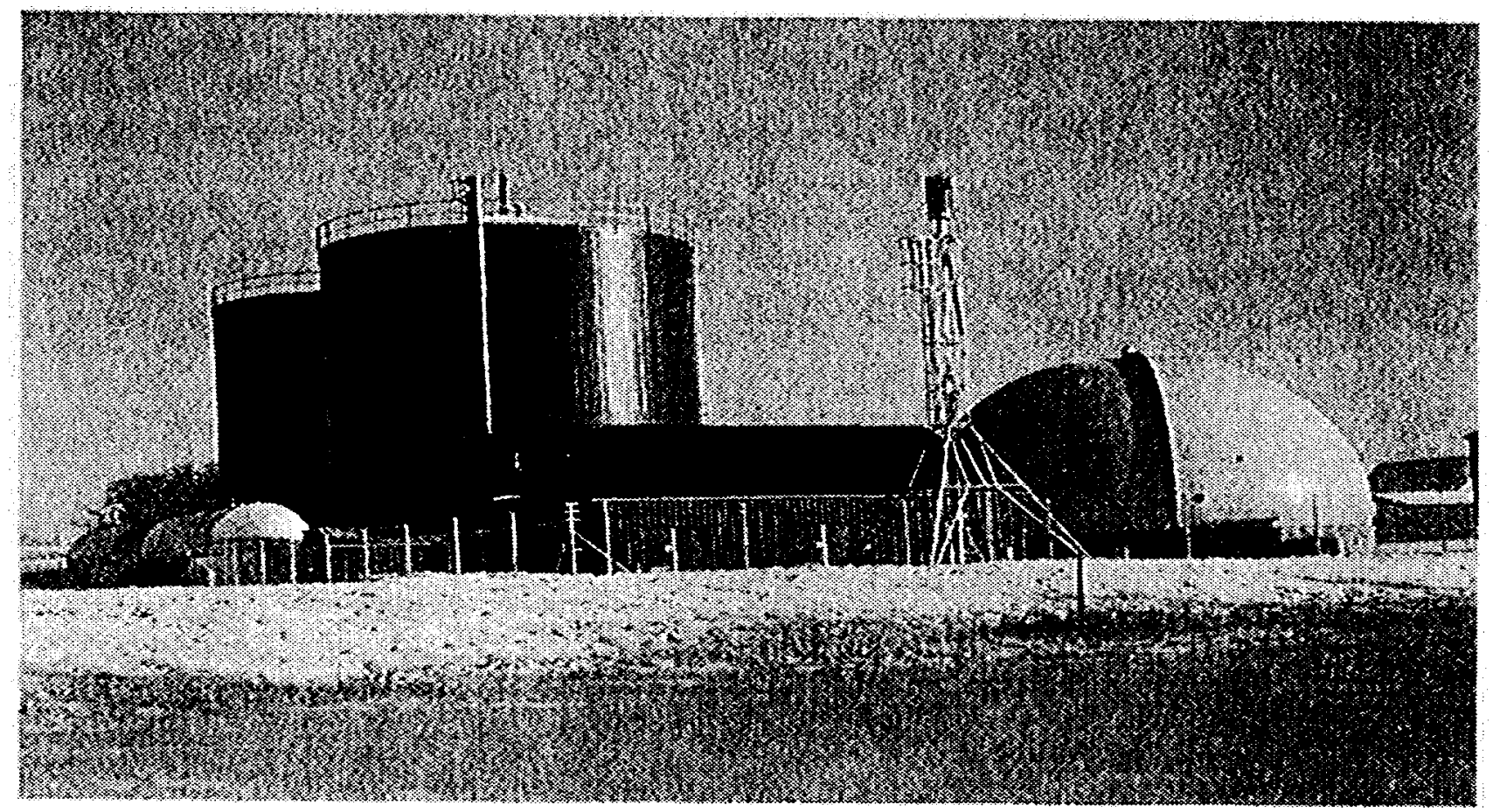

Figure 1. Centralized biogas plant for thermophilic anaerobic digestion of animal manure, at Thorso, Denmark.

\section{Anaerobic Digestion of Municipal Solid Wastes}

The development of anaerobic digestion technologies that can ferment high-solids feedstocks such as municipal solid wastes began in the $1980 \mathrm{~s}$. The first generation of these plants is now coming into service, mostly in Germany, Denmark, Belgium, and the Netherlands (IEA 1994). Figure 2 shows the plant used to treat source-separated biowaste from the city of Salzburg. Austria. The ability of these plants to handle high-solids feedstocks also makes them useful for improving the overall energy and environmental aspects of emerging renewable biomass technologies.

\section{Biogas from Biomass}

Most biogas produced in agriculture comes from intensive livestock production. Here biogas is collected as a by-product of an environmental protection process. But energy crops such as silage grass, myscanthus, or sugar beet leaves can also be used as direct feedstocks for biogas production in a dedicated anaerobic digestion plant. The process offers a net energy yield of $52.9 \mathrm{GJ} / \mathrm{ha}$ (CEC 1994a), but biogas and methane are not convenient fuels for vehicle propulsion and need to be used on-site or exported (as electricity) to the local power utility. 


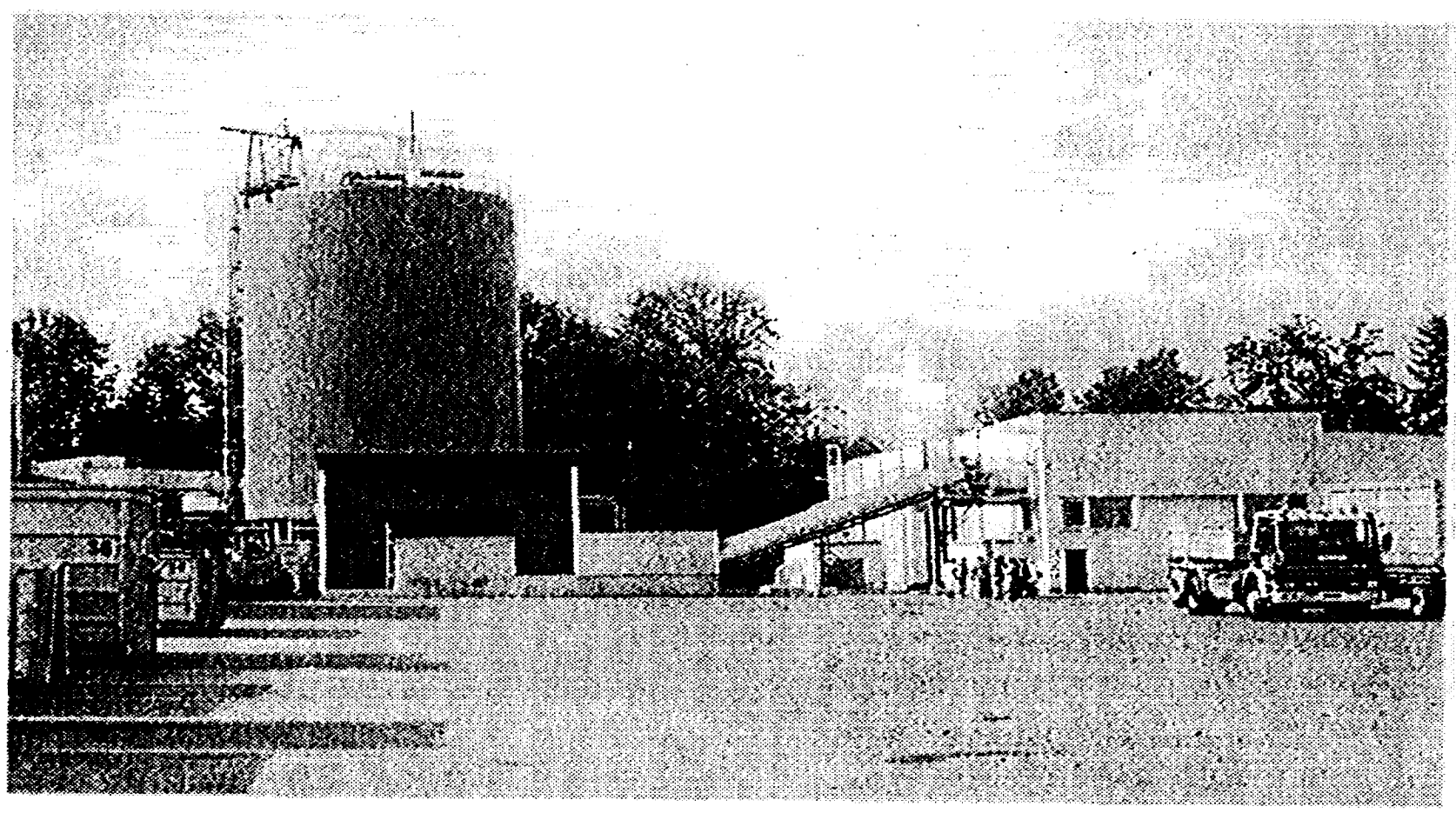

Figure 2. High-solids anaerobic digestion of $55 \mathrm{t} / \mathrm{d}$ of source-separated municipal biowaste from the city of Salzburg, Austria.

\section{Biogas from Biofuel Residues}

Most biomass-to-energy schemes are targeted to producing the energy as a liquid fuel (vegetable oil or ethanol), which can be sold off-site as vehicle fuel. Here the role of anaerobic digestion would be to extract residual energy values from surplus by-products to improve the overall energy efficiency and economics of the scheme. 


\section{Biogas and Biodiesel}

More than 300 plant species can be used to produce vegetable oils, with the highest yields usually found in tree crops (palm oil, olive oil, etc). Field crops such as rapeseed or sunflower seeds are easier to harvest. The simplest method of extracting the raw oil is in a screw press or expeller, followed by solvent extraction of the residual press cake. The recovered oil then needs to be chemically modified to convert the original triglycerides into the methyl esters of their component long-chain fatty acids. A typical conversion of rapeseed oil would be:

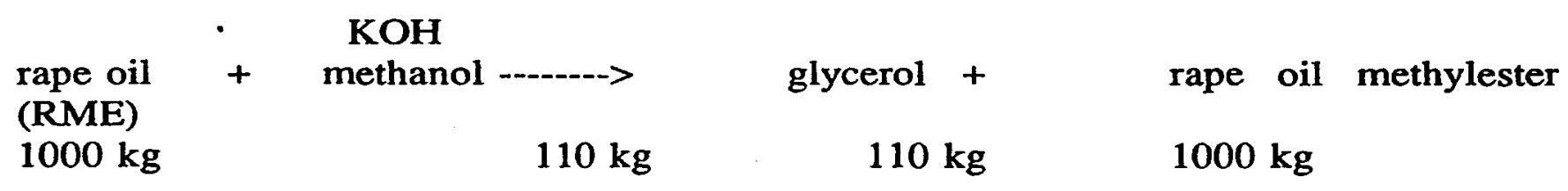

Typically, 1 ha of rape crop would produce about $3000 \mathrm{~kg}$ of rapeseeds, which would eventually yield about:

$\begin{array}{ll}1000 \mathrm{~kg} \text { rape oil methyl ester } & \text { for vehicle fuel } \\ 1900 \mathrm{~kg} \text { pressed seed cake } & \text { for animal feed } \\ 110 \mathrm{~kg} \text { glycerol } & \text { for chemical feedstock }\end{array}$

An overall energy flow diagram for producing rape oil methylester (biodiesel) is shown in Figure 3. The net energy yield of $47.8 \mathrm{GJ} / \mathrm{ha}$ is comparable with putting the same field to silage for biogas production, but the energy has been captured in a much more versatile liquid fuel. The problems begin when the markets for biodiesel by-products (rapeseed meal and glycerine) become saturated. But it doesn't have to be so, because you can have your biodiesel and biogas as well. Anaerobic digestion could convert about half the 28.2 GJ/ha in the surplus rapeseed meal into biogas, conserving its nutrients and providing a stabilized residue for recycling back to the crop.

\section{Biogas and Bioethanol}

A wide range of crops can be grown to provide sugars and starches for fermentation to ethanol. Their yields and climate ranges vary, but they all produce a high proportion of wastes and by-products that require marketing, processing, or disposal. Anaerobic wastewater plants are already used to treat wastewaters from sugar refineries and vinasses from ethanol distilleries. Separate high-solids digesters could yield even more biogas from plant residues and pulps. 


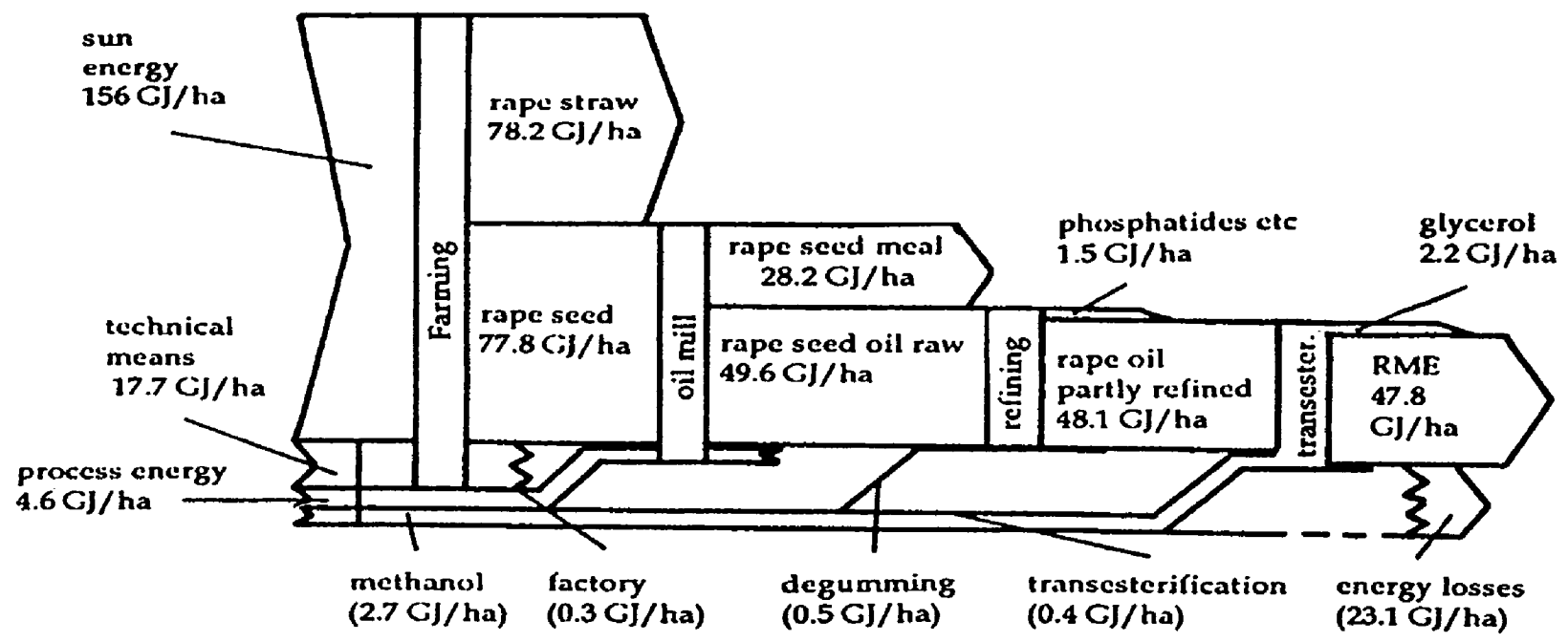

Figure 3. Energy flow diagram for the production of rape oil methylester (CEC 1994b)

\section{Recycling Biomass Residues Back to the Crop}

\section{Plant Nutrients for Field Crops}

Field crops tend to be hungry for nutrients, and their fertilizer requirements make a significant impact on the overall energy balance and economics of biomass-to-energy schemes. Anaerobic digestion and composting both have a role to play in promoting the effective recycling of plant nutrients back to the growing crop. Both processes stabilize the organic residues to improve their storage and distribution characteristics. Anaerobic digestion is particularly well suited to processing wet pulps and soft, squashy residues that become more liquid and easier to pump. It also converts a proportion of the bound nitrogen into soluble ammonium ions for immediate uptake by the plants. Nutrient requirements of some common field crops are summarized in Table 2.

Table 2. Typical Nutrient and Pesticide Requirements of Some Common Crops as a Percentage of Total Yield

(Dry Farming in a North American Climate-CEC 1994d)

\begin{tabular}{|l|c|c|c|c|c|}
\hline & $\begin{array}{c}\text { Sorghum } \\
\text { (Kansas) }\end{array}$ & $\begin{array}{c}\text { Soybeans } \\
\text { (Illinois) }\end{array}$ & $\begin{array}{c}\text { Safflowers } \\
\text { (California) }\end{array}$ & $\begin{array}{c}\text { Sugar Beet } \\
\text { (California) }\end{array}$ & $\begin{array}{c}\text { Sugar Cane } \\
\text { (Louisiana) }\end{array}$ \\
\hline Nitrogen & 20.54 & 2.64 & 70.58 & 3.54 & 33.71 \\
\hline Phosphates & 1.84 & 9.02 & 41.76 & 0.00 & 20.69 \\
\hline Potassium & 0.48 & 8.52 & -- & -- & 31.79 \\
\hline Insecticides & 0.32 & -- & -- & 0.04 & 0.53 \\
\hline Herbicides & 0.54 & 1.43 & -- & -- & 1.32 \\
\hline $\begin{array}{l}\text { Total yield } \\
\text { (kg/ha) }\end{array}$ & 1840 & 1994 & 1700 & 53644 & 4687 \\
\hline
\end{tabular}




\section{Organic Matter and Humus for Marginal Land}

For upgrading marginal land and reclaiming derelict land, the prime requirement is for bulk quantities of well-rotted organic matter (humus) to improve the soil's physical structure and water retention. Digested or composted biomass residues are equally suitable, with composting being the most obvious choice for highly structured woody residues (and vice versa).

\section{Slow-Release Fertilizers for Forestry}

For forestry, and especially when planting young trees, the requirement is for slow-release fertilizers from digestate solids or composted crop residues that can nurture the young trees through their first years of growth. Early addition of quick-release soluble nitrogen simply produces a sudden flush of rank grass.

\section{Anaerobic Digestion as an Odor-Abatement Technology}

The methanogenic fermentation at the heart of the anaerobic digestion process destroys the malodorous organic compounds commonly associated with simple anaerobic putrefaction. High-nitrogen wastes will still have some residual odor from ammonia, and high-sulphur wastes will tend to generate hydrogen sulphide, but other odors are very effectively destroyed.

\section{Anaerobic Digestion for Pathogen Destruction}

Anaerobic digestion is one of several processes available for disinfecting or sanitizing waste materials to permit their safe return to the environment, and is very widely used around the world to deodorize and disinfect high-risk materials such as sewage sludge. Regulations concerning the precise degree of sanitization required vary from country to country. UK practice is summarized in Table 3, which lists those processes considered to be effective barriers to infection in the UK.

Originally developed to protect public health and farm livestock, these processes and codes of practice also provide a useful barrier to infection of the growing crop by diseased plant residues and crop pests from the central biomass processing plant.

\section{Visual and Amenity Aspects of Anaerobic Digestion Plants}

Anaerobic digestion plants comprise mostly enclosed tanks with a similar appearance to the grain stores commonly found on farms in the American Midwest. The anaerobic digestion tanks themselves are generally odor-free, quiet, and unobtrusive. Any peripheral problems with odors, gaseous emissions, noise, or road traffic tend to arise from the loading/unloading or pre-processing of raw feedstocks or digestate products. These areas of the plant need to be carefully designed to ensure that they too are unobtrusive and "neighborhood-friendly." Road traffic can sometimes be a problem where the plants are processing large throughputs of a bulky feedstock, and the plants need to be carefully located to minimize haulage distance and provide good vehicle access. 
Table 3. Treatment Processes for Sewage Sludge (as Defined by the UK DOE Code of Practice for Agricultural Use of Sewage Sludge)

\begin{tabular}{|c|c|}
\hline Process & Description \\
\hline Pasteurization & $\begin{array}{l}\text { Minimum of } 30 \mathrm{~min} \text { at } 70^{\circ} \mathrm{C} \text { or minimum of } 4 \mathrm{~h} \text { at } 55^{\circ} \mathrm{C} \\
\text { (or appropriate intermediate conditions), followed in all } \\
\text { cases by primary mesophilic anaerobic digestion. }\end{array}$ \\
\hline $\begin{array}{l}\text { Mesophilic Anaerobic } \\
\text { Digestion }\end{array}$ & $\begin{array}{l}\text { Mean retention period of at least } 12 \mathrm{~d} \text { primary digestion in } \\
\text { temperature range } 35^{\circ} \mathrm{C}+3^{\circ} \mathrm{C} \text {, or of at least } 20 \mathrm{~d} \text { primary } \\
\text { digestion in temperature range } 25^{\circ} \mathrm{C}+3^{\circ} \mathrm{C} \text {, followed in each } \\
\text { case by a secondary stage that provides a mean retention } \\
\text { period of at least } 14 \mathrm{~d} \text {. }\end{array}$ \\
\hline $\begin{array}{l}\text { Thermophilic Aerobic } \\
\text { Digestion }\end{array}$ & $\begin{array}{l}\text { Mean retention period of at least } 7 \mathrm{~d} \text { digestion. All sludge } \\
\text { to be subject to a minimum of } 55^{\circ} \mathrm{C} \text { for at least } 4 \mathrm{~h} \text {. }\end{array}$ \\
\hline $\begin{array}{l}\text { Composting in } \\
\text { Windrows or Aerated } \\
\text { Piles }\end{array}$ & $\begin{array}{l}\text { The compost must be maintained at } 40^{\circ} \mathrm{C} \text { for at least } 5 \mathrm{~d} \\
\text { and for } 4 \mathrm{~h} \text { during this period at a minimum of } 55^{\circ} \mathrm{C} \\
\text { within the body of the pile, followed by a period of } \\
\text { maturation adequate to ensure that the compost reaction is } \\
\text { substantially complete. }\end{array}$ \\
\hline $\begin{array}{l}\text { Lime Stabilization of } \\
\text { Liquid Sludge }\end{array}$ & $\begin{array}{l}\text { Addition of lime to raise } \mathrm{pH} \text { to greater than } 12.0 \text { and } \\
\text { sufficient to ensure that the } \mathrm{pH} \text { is not less than } 12.0 \text { for at } \\
\text { least } 2 \mathrm{~h} \text {. The sludge can then be used directly. }\end{array}$ \\
\hline Liquid Storage & Storage of untreated liquid sludge for at least $3 \mathrm{mo}$. \\
\hline $\begin{array}{l}\text { Dewatering and } \\
\text { Storage }\end{array}$ & $\begin{array}{l}\text { Conditioning of untreated sludge with lime or other } \\
\text { coagulants followed by dewatering and storage of the cake } \\
\text { for at least } 3 \text { mo. If sludge has been subject to primary } \\
\text { mesophilic anaerobic digestion, storage to be for at least } \\
14 \mathrm{~d} \text {. }\end{array}$ \\
\hline
\end{tabular}

\section{Summary and Conclusions}

Natural methane fermentations occur widely in the environment and form an integral part of the life processes of our planet. Methane released into the atmosphere has been increased in recent years by intensive livestock farming, deposition of large quantities of putrescible solid wastes in landfills and by the release of geological methane during the extraction, distribution, and use of fossil fuels. There is an environmental need to capture this methane and put it to use as fuel to benefit mankind and his habitat. Simply flaring off surplus biogas is wasteful but it does, at least, decrease the greenhouse effect of the gas because, molecule for molecule, carbon dioxide is 20 times less powerful than methane as a greenhouse gas. Using the gas as a renewable fuel is a better environmental option. It conserves fossil fuel resources and decreases overall emissions of carbon dioxide to the atmosphere. It also make good economic sense and substantially improves the energy efficiency and economic cash flows of other biomass-to-energy schemes. 


\section{References}

CEC. (1994a). "Gaseous Biofuels: Biogas and Producer Gas," in Biofuels: Application of Biologically Derived Products as Fuels or Additives in Combustion Engines, European Commission Directorate-General XII, Science, Research and Development, EU 15647 EN, pp. 52-67.

CEC. (1994b). "Plant Oils and Methylesters," in Biofuels: Application of Biologically Derived Products as Fuels or Additives in Combustion Engines, European Commission Directorate-General XII, Science, Research and Development, EU 15647 EN, pp.2-20.

CEC. (1994c). "Alcohols: Ethanol and Methanol," in Biofuels: Application of Biologically Derived Products as Fuels or Additives in Combustion Engines, European Commission Directorate-General XII, Science, Research and Development, EU 15647 EN, pp. 22-50.

CEC. (1994d). "Biofuels for Motor Vehicles," in Biofuels: Application of Biologically Derived Products as Fuels or Additives in Combustion Engines, European Commission Directorate-General XII, Science, Research and Development, EU 15647 EN, pp. 104-122.

DOE. (1989). "Code of Practice for Agricultural Use of Sewage Sludge," London, HMSO, ISBN 0117522562.

Huub, J.M. et al. (1988). "Effect of Lignin on the Microbial Degradation of (Ligno)cellulosic Wastes by Rumen Microorganisms," Applied Microbiology and Biotechnology 29, pp. 408-412.

[EA. (1994). "Biogas from Municipal Solid Waste," published by Danish Energy Agency, Copenhagen, Denmark, July 1994.

Makansi, J. (1984). "Power from Sludge," Power 128, February, pp. S1-S16. 


\title{
ECONOMIC VIABILITY OF ANAEROBIC DIGESTION
}

\author{
Arthur Wellinger \\ Head of INFOENERGIE \\ 8356 Ettenhausen, Switzerland
}

\begin{abstract}
The industrial application of anaerobic digestion is a relatively new, yet proven waste treatment technology. Anaerobic digestion reduces and upgrades organic waste, and is a good way to control air pollution as it reduces methane and nitrous gas emissions.

For environmental and energy considerations, anaerobic digestion is a nearly perfect waste treatment process. However, its economic viability is still in question. A number of parameters -type of waste (solid or liquid), digester system, facility size, product quality and end use, environmental requirements, cost of alternative treatments (including labor), and interest rates - define the investment and operating costs of an anaerobic digestion facility. Therefore, identical facilities that treat the same amount and type of waste may, depending on location, legislation, and end product characteristics, reveal radically different costs.

A good approach for evaluating the economics of anaerobic digestion is to compare it to treatment techniques such as aeration or conventional sewage treatment (for industrial wastewater), or composting and incineration (for solid organic waste). For example, the cost (per ton of waste) of in-vessel composting with biofilters is somewhat higher than that of anaerobic digestion, but the investment costs $11 / 2$ to 2 times more than either composting or anaerobic digestion. Two distinct advantages of anaerobic digestion are: (1) it requires less land than either composting or incinerating, which translates into lower costs and milder environmental and community impacts (especially in densely populated areas); and (2) it produces net energy, which can be used to operate the facility or sold to nearby industries.
\end{abstract}




\section{Introductory Remarks}

The industrial application of anaerobic digestion (AD) is a relatively new, yet proven waste treatment technology. Anaerobic digestion reduces and upgrades organic waste, and is a good way to control air pollution as it reduces methane and nitrous gas emissions.

The political implication of environmental control makes evaluating the economics of AD on an international scale extremely difficult. A number of country-specific parameters define the investment and the operation and maintenance (O\&M) costs such as the type of waste (liquid, solid), digester system, size of installation, quality and end use of the products, environmental requirements, cost and labor of alternative treatments, interest rates, etc. As a result, identical installations treating the same amount and type of waste might lead to different costs in different countries.

Table 1 compiles of the most important parameters. Sensitivity analyses are not detailed; however, preliminary evaluations seem to indicate that legislation and the price of electricity predominate. Equally important are the external or social costs, i.e., environment and health not covered by the actual energy price but paid by the entire society, in particular by future generations. They are internalized, i.e., added to the energy price, and they can drastically disfavor some current waste treatment techniques. In summary, the profitability of waste treatment processes is equally defined by political decisions and engineering solutions.

\section{Table 1: Influence of Various Parameters on Investment and Running Costs of Anaerobic Digesters}

\begin{tabular}{||l|l|l||}
\hline $\begin{array}{c}\text { Parameters Influencing } \\
\text { the Economy }\end{array}$ & \multicolumn{1}{|c|}{$\begin{array}{c}\text { Major Effect on } \\
\text { Running Cost }\end{array}$} & \multicolumn{1}{|c|}{$\begin{array}{c}\text { Major Effect on } \\
\text { Investment Cost }\end{array}$} \\
\hline Type of Equipment & $\begin{array}{l}\text { Pretreatment } \\
\text { Type of Digester } \\
\text { Upgrade of Biogas } \\
\text { Chemical Additives }\end{array}$ & $\begin{array}{l}\text { Pretreatment } \\
\text { Type of Digester } \\
\text { Upgrade of Biogas } \\
\text { Use of Biogas } \\
\text { Storage of Biogas }\end{array}$ \\
\hline Capacity & $\begin{array}{l}\text { Efficiency of Electricity } \\
\text { Production }\end{array}$ & Economy of Scale \\
\hline Profitability & $\begin{array}{l}\text { Interest Rates } \\
\text { Taxes } \\
\text { Amortization }\end{array}$ & $\begin{array}{l}\text { Subsidies } \\
\text { Eost-Treatment }\end{array}$ \\
\hline Laws & $\begin{array}{l}\text { End Use of Products } \\
\text { Insurance } \\
\text { Transportation Cost }\end{array}$ & $\begin{array}{l}\text { Post Treatment } \\
\text { Impact Studies } \\
\text { Security Requirements }\end{array}$ \\
\hline Last of Living & $\begin{array}{l}\text { Labor } \\
\text { Land Prices }\end{array}$ \\
\hline
\end{tabular}




\begin{tabular}{||c|c|c||}
\hline $\begin{array}{c}\text { Parameters Influencing } \\
\text { the Economy }\end{array}$ & \multicolumn{1}{|c|}{$\begin{array}{c}\text { Major Effect on } \\
\text { Running Cost }\end{array}$} & $\begin{array}{c}\text { Major Effect on } \\
\text { Investment Cost }\end{array}$ \\
\hline \hline Type of Waste & $\begin{array}{c}\text { Biological Oxygen } \\
\text { Demand (BOD) } \\
\text { Content Inhibitors }\end{array}$ & Source Separation \\
\hline
\end{tabular}

\section{Economical Considerations of Different Process Designs}

Like other waste treatment processes, not all kinds of organic materials can be treated anaerobically in the same type of installation. Three basic designs of digesters can be distinguished for municipal solid waste (MSW), for liquid (solubilized) waste (industrial waste water), and for heterorganic waste (animal manure). Economical comparisons can reasonably be done only within the respective types of waste. The examples given below were evaluated in project studies for a same object in 1992. The young market of AD moves fast; hence, the absolute figures no longer reflect the actual situation. However, the comparative significance between the different procedures is still valuable.

\section{Municipal Solid Waste Digestion}

In Europe, source separation of household waste is widespread. Common fractions are: metals, glass, polyethylene terephthalate (PET), paper, organics and the remaining fraction. The goals of separate collection are to recycle and reduce the waste volume to be landfilled or incinerated. In particular, removing the humid organic fraction leads to lower emissions of methane and volatile organic carbons (VOCs) when landfilled or to higher heating values when incinerated. In the European Union, landfilling organic material will be drastically decreased and ultimately prohibited.

With the increasing requirements for stack gas treatment $\left(\mathrm{CO}\right.$, ashes, $\mathrm{NO}_{\mathrm{x}}$, dioxins) and the need to solidify the ashes, incineration became a very expensive technique (Figure 1). Reducing the volume by source separating the organic fraction will therefore reduce costs. Composting or $\mathrm{AD}$ are the two methods of choice to upgrade the organic fraction. Both techniques yield high-quality humus that can be recycled to replace imported peat.

The main distinctive advantages of $\mathrm{AD}$ over composting are that it:

- produces net energy (Table 2)

- reduces greenhouse gas emissions

- requires less land, which translates into lesser effects on the community

- has fewer odor emissions 
Figure 1: Average Prices for Landfilling and Incineration in Selected Countries

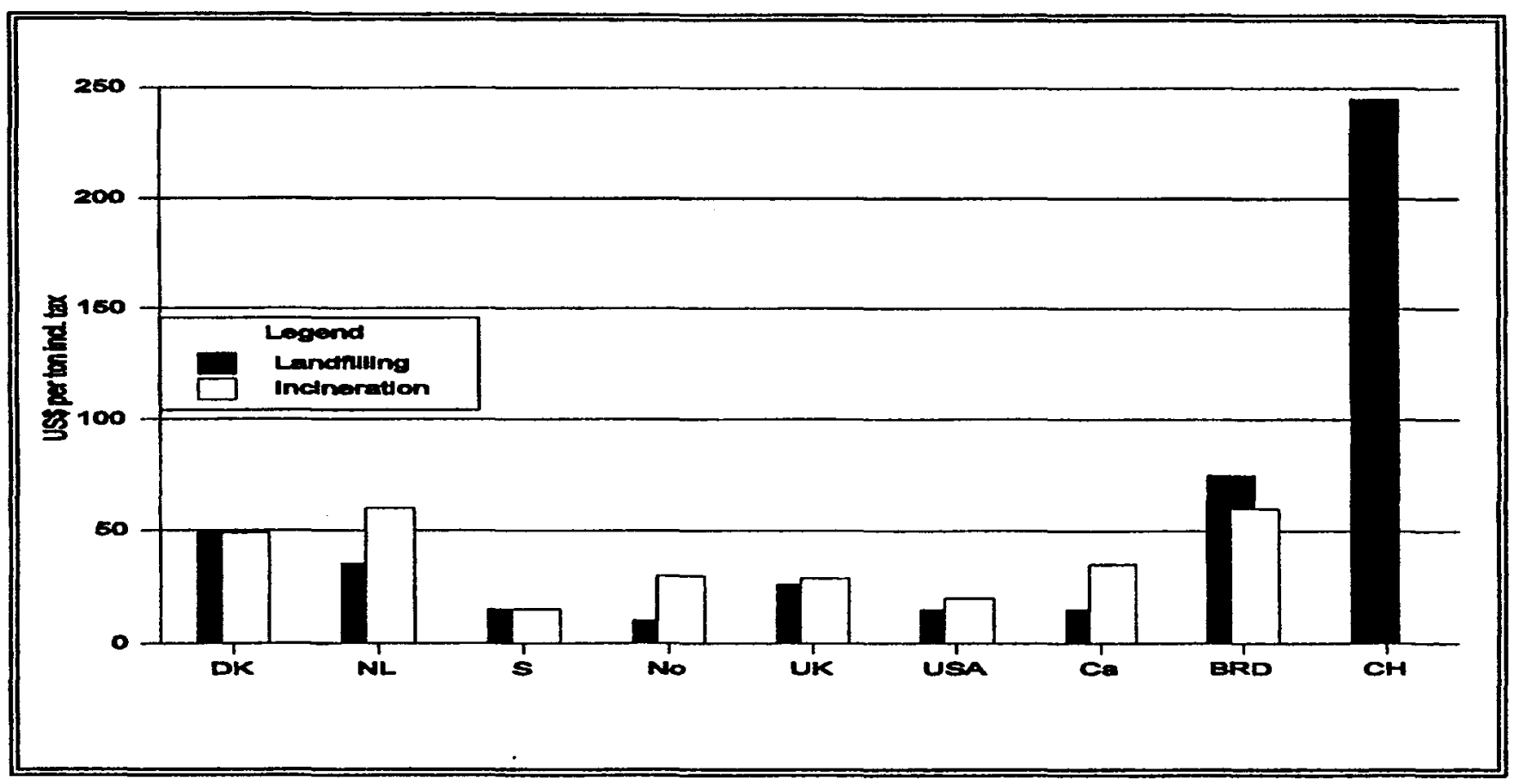

Table 2: Energy Balances of Aerobic and Anaerobic Processes (adapted from Edelmann et al. 1994)

\begin{tabular}{|c|c|c|c|c|c|c|}
\hline \multirow[t]{2}{*}{ System } & \multicolumn{3}{|c|}{ Composting } & \multicolumn{3}{|c|}{ Anaerobic Digestion } \\
\hline & Box & Indoor & Tunnel & $\begin{array}{l}\text { Thermo- } \\
\text { philic }\end{array}$ & $\begin{array}{l}\text { Thermo- } \\
\text { philic }\end{array}$ & $\begin{array}{l}\text { Meso- } \\
\text { philic }\end{array}$ \\
\hline Producer & BIOCON & BUHLER & BAV & $\begin{array}{l}\text { KOMPO- } \\
\text { GAS }\end{array}$ & $\begin{array}{c}\text { DRAN- } \\
\text { CO }\end{array}$ & $\begin{array}{l}\text { VALOR- } \\
\text { GA }\end{array}$ \\
\hline $\begin{array}{l}\text { Capacity } \\
\text { (t/a) }\end{array}$ & 50,000 & 40,000 & 50,000 & 10,000 & 50,000 & 52,000 \\
\hline $\begin{array}{l}\text { Electric- } \\
\text { ity Con- } \\
\text { sumption } \\
(\mathrm{kWh} / \mathrm{t})\end{array}$ & 20 & 35 & 25 & 35 & 33 & 75 \\
\hline $\begin{array}{l}\text { Electric- } \\
\text { ity Prod- } \\
\text { uction } \\
(\mathrm{kWh} / \mathrm{ta})\end{array}$ & -20 & -35 & -25 & 75 & 79 & 78 \\
\hline
\end{tabular}

The application of aerobic composting to MSW is that the wet organic waste tends to compact and oxygen transfer during composting becomes limited. As a result, the 
compost starts stinking and eventually may even "sour." MSW therefore must be composted in closed halls together with the addition parts of dry organic material which increases air flow through the material. In this way composting tends to become slightly more expensive that anaerobic digestion (Table 3).

In contrast, a Dutch study (Haskoning 1993) with data from 1990 found that composting was approximately $20 \%$ to $40 \%$ cheaper than $\mathrm{AD}$ in the range of 120,000 to 25,000 tons per year. However, this evaluation was not site specific. In addition, AD was not well established at that time, and offers still had a relatively high security factor.

Both biological treatments are much cheaper than incineration. The example of the VALORGA plant indicates a distinct economy of scale. Construction and running cost of AD were reduced during the past two years thanks to experience gained and increasing competition. But still there is a clear-cut specific cost. The comparable costs of the large-scale plant are $\$ 208$ per ton for incineration and $\$ 99$ per ton for landfilling.

Table 3: Comparison of Investment on Running Cost of MSW Treatment (adapted from Edelmann et al. 1993)

\begin{tabular}{|c|c|c|c|c|c|}
\hline \multirow[t]{2}{*}{ System } & \multicolumn{4}{|c|}{ Anaerobic Digestion } & Composting \\
\hline & $\begin{array}{l}\text { DRANCO } \\
1992\end{array}$ & $\begin{array}{l}\text { KOMPO- } \\
\text { GAS } \\
1992\end{array}$ & $\begin{array}{l}\text { VALOR- } \\
\text { GA } \\
1992\end{array}$ & $\begin{array}{l}\text { VALOR- } \\
\text { GA } \\
1994\end{array}$ & $\begin{array}{l}\text { INDOOR } \\
\text { WINDROW } \\
1992\end{array}$ \\
\hline Capacity (t/a) & 10,000 & 10,000 & 10,000 & 52,000 & 10,000 \\
\hline $\begin{array}{l}\text { Investment } \\
\text { Cost }\end{array}$ & $\begin{array}{c}\text { US } \$ \\
6,286,200\end{array}$ & $\begin{array}{c}\text { US\$ } \\
5,666,000\end{array}$ & $\begin{array}{c}\text { US } \$ \\
9,861,500\end{array}$ & $\begin{array}{c}\text { US } \$ \\
34300,000\end{array}$ & $\begin{array}{c}\text { US\$ } \\
8,331,200\end{array}$ \\
\hline $\begin{array}{l}\text { Running Cost } \\
\text { - Capital } \\
\text { - Operation \& } \\
\text { Maintenance } \\
\text { - Personnel } \\
\text { - Divers } \\
\text { Total Running } \\
\text { Cost }\end{array}$ & $\begin{array}{l}734,200 \\
167,600 \\
146,000 \\
190,000 \\
1,237,800\end{array}$ & $\begin{array}{l}608,400 \\
135,000 \\
146,000 \\
179,700 \\
1,069,100\end{array}$ & $\begin{array}{c}1,087,300 \\
258,500 \\
146,000 \\
221,700 \\
1,713,500\end{array}$ & $\begin{array}{c}3,118,500 \\
311,900 \\
727,700 \\
519,700 \\
4,667,800\end{array}$ & $\begin{array}{l}889,800 \\
207,800 \\
219,000 \\
206,400 \\
1,523,000 \\
\end{array}$ \\
\hline $\begin{array}{l}\text { Specific Cost } \\
\text { With Land } \\
\text { Without Land }\end{array}$ & $\begin{array}{c}\text { US\$/ton } \\
123 \\
121\end{array}$ & $\begin{array}{c}\text { US\$/ton } \\
107 \\
105\end{array}$ & $\begin{array}{c}\text { US\$/ton } \\
172 \\
168\end{array}$ & $\begin{array}{c}\text { US\$/ton } \\
104\end{array}$ & $\begin{array}{c}\text { US\$/ton } \\
152 \\
142\end{array}$ \\
\hline
\end{tabular}

\section{Digestion of Industrial Wastewater}

Most often AD is used as a first step in the treatment of high-strength wastewater (more than 2,000 ppm chemical oxygen demand [COD] to reduce the cost of sewage treatment.) The digested material overflows in the sewer. Sometimes AD is followed by a 
denitrification step. In a few cases, particularly in developing countries, AD-eventually followed by an aeration step-is used as a full treatment of wastewater. Most of the 13 plants in Switzerland were erected because the treatment cost was lower than a necessary upscale of the sewage treatment plant because of higher industrial production. In one case, $\mathrm{AD}$ was introduced to minimize the odor problems from the sewage treatment plant, which evoked complaints from residents. The differences of treatment cost between the various $A D$ procedures are marginal (Table 4). However, $A D$ is always more cost effective than aeration, which often is not considered alone because of its space requirement.

Table 4: Comparison of Investment and Running Costs of Industrial Wastewater Treatment (adapted from Edelmann et al. 1993)

\begin{tabular}{|c|c|c|c|c|c|c|}
\hline \multicolumn{2}{|l|}{ System } & Contact & UASB- & Fluidized & Contact & Aeration \\
\hline $\begin{array}{l}\text { Performance } \\
\text { Wastewater } \\
\text { COD-Load }\end{array}$ & $\begin{array}{l}\mathrm{m}^{3} / \mathrm{d} \\
\mathrm{m}^{3} / \mathrm{a} \\
\mathrm{kg} / \mathrm{d} \\
\mathrm{kg} / \mathrm{a}\end{array}$ & $\begin{array}{r}6,000 \\
1500,000 \\
10,000 \\
2500,000 \\
\end{array}$ & $\begin{array}{r}6,000 \\
1500,000 \\
10,000 \\
2500,000 \\
\end{array}$ & $\begin{array}{r}6,000 \\
1500,000 \\
10,000 \\
2500,000 \\
\end{array}$ & $\begin{array}{r}1,600 \\
580,000 \\
9,600 \\
2500,000 \\
\end{array}$ & $\begin{array}{r}1,600 \\
580,000 \\
9,600 \\
2500,000 \\
\end{array}$ \\
\hline $\begin{array}{l}\text { Investment } \\
\text { Cost }\end{array}$ & US\$ & 5923,000 & 5961,500 & 5461,500 & 1100,000 & 1200,000 \\
\hline $\begin{array}{l}\text { Running Cost } \\
\text { - Capital } \\
\text { - Operation \& } \\
\text { Maintenance } \\
\text { - Energy } \\
\text { - Personnel } \\
\text { - Divers } \\
\text { Total Running } \\
\text { Cost }\end{array}$ & $\begin{array}{l}\text { US\$/ } \\
\text { a }\end{array}$ & $\begin{array}{r}681,000 \\
115,000 \\
\\
-98,400 \\
69,000 \\
443,800 \\
1210,400\end{array}$ & $\begin{array}{r}644,400 \\
96,000 \\
\\
-130,000 \\
69,000 \\
444,200 \\
1123,600\end{array}$ & $\begin{array}{r}627,000 \\
105,000 \\
\\
-80,700 \\
699,000 \\
439,200 \\
1159,500\end{array}$ & $\begin{array}{r}52,000 \\
156,000\end{array}$ & $\begin{array}{r}300,000 \\
98,000\end{array}$ \\
\hline Specific Cost & $\begin{array}{l}\text { US\$/ } \\
\mathrm{m}^{3} \\
\mathrm{US} \$ / \\
\mathrm{kg} \\
\mathrm{CSB}\end{array}$ & $\begin{array}{l}0.80 \\
0.48\end{array}$ & $\begin{array}{l}0.74 \\
0.45\end{array}$ & $\begin{array}{l}0.77 \\
0.46\end{array}$ & & \\
\hline
\end{tabular}

\section{Digestion of Agricultural Wastes}

AD of industrial or municipal wastes has to compete with alternative procedures with relatively high treatment cost. It is therefore easy to reach economic compatibility. With agricultural wastes, economic viability has to be reached by biogas production alone. Advantages such as improving fertilizer quality or reducing the environmental impact of 
manure are hardly taken into account. Hence, the potential for constructing economically viable digesters is rather limited.

The few solutions discussed below deal with cattle only. However, all systems apply to pig manure. In fact, chances of economical feasibility with swine waste are far better because it has higher specific gas potential.

In Europe farm sizes are very small. Typical sizes for biogas farms vary between $\mathbf{3 0}$ and 50 cattle units (CU) ( $1 \mathrm{CU}$ is equivalent to $500 \mathrm{~kg}$ live weight). To be profitable investments costs must generally be lower than $\$ 750$ per CU. Essentially this means either partial self-construction or a joint central biogas plant.

An alternative to low construction cost is the addition of industrial waste material from slaughterhouses, fish processing, tanneries, milk and vegetable processing, etc., which yield high gas production and bring an additional gain through treatment fees.

Iñ a number of European countries biogas installations are subsidized either by direct support or indirectly through high market prices for the electricity fed to the grid (Figure 2).

\section{Figure 2: Market Prices of Electricity Produced from Biogas}

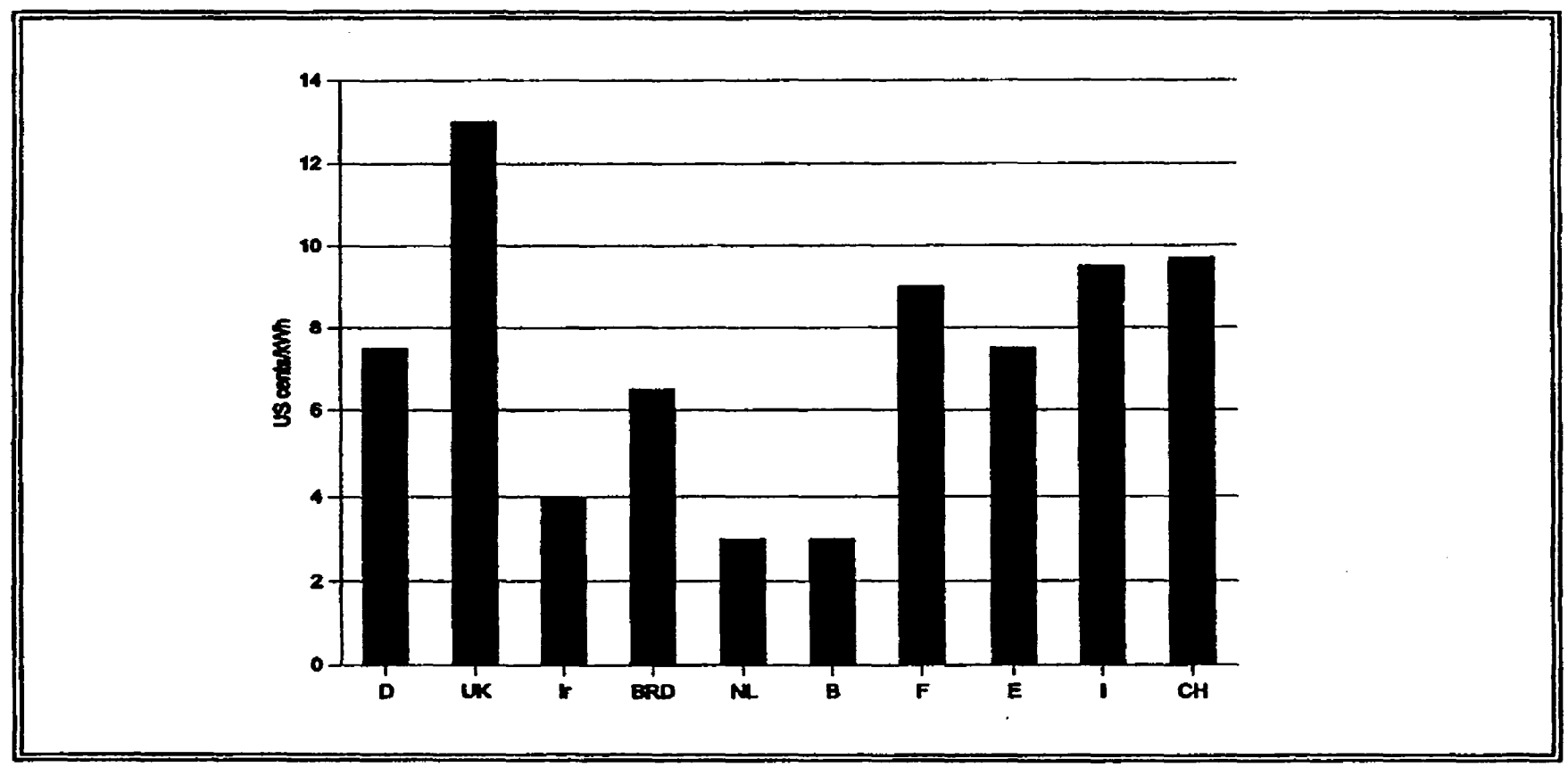

A number of small-scale on-farm biogas installations (accumulation systems) in Germany and in Switzerland have payback periods of less than 13 years, which is the estimated average lifetime of a biogas installation. Profitability was reached by self-construction, subsidies, and in part by adding other waste materials. On the basis of the best run biogas plants in Denmark, joint biogas plants can be operated profitably (Danish Energy Agency 1991), with a few preconditions: 
- Supplement at least $15 \%$ industrial waste

- Use the biogas produced steadily, with high subsidized market prices for the electricity

- Abundant manure must be available within a reasonable radius

- Plant management must keep O\&M cost low

In the U.S. the income is less favorable. Both electricity and heat; i.e. fuel prices, are far lower than in Europe. On the other hand, specific investment cost can be kept low because of the large herd sizes. The economy of scale allows a favorable economy with the same simple digester designs as in Europe. A recent study on operating U.S. biogas plants (Lusk 1994) shows that covered lagoons and mixed systems were built at reasonably low prices from $\$ 250$ (750 head) to $\$ 400$ (300 head) per head of cattle. A more detailed economical analysis was not possible, because data of the amount of manure actually fed into the digester could not be determined. Instead, the author has developed an economical model for herd sizes from 250 to 1000 head. He assumed technically and volumetrically optimized digesters with cost from $\$ 96$ to $\$ 374$ per head of cattle as a function of herd size (250 or 500 head), designed (covered lagoon, completely stirred tank) and collected amount of manure (14\% or 55\%). Within this framework a positive cash flow was calculated with simple payback periods of less than 13 years. This strongly indicates that biogas production from agricultural waste is economically feasible in the U.S.

\section{Energy and Environmental Legislation}

Legislation has the strongest potential impact on the economy of $\mathrm{AD}$. The higher the environmental requirements, the higher the cost of conventional processes; i.e., the better applicability of $A D$, which is a proven clean technology. Swiss standards on emission of stack gases and requirements for landfilling ashes and products of advanced flue gas treatment (denox) render incineration extremely expensive (Figure 1). AD of the organic fraction is therefore a valuable, low-cost alternative.

The requirement for very clean composts after $\mathrm{AD}$ increases the cost of waste separation and control before and after collection. The concentrations of heavy metals and other toxic substances must meet national guidelines. The product also must be visually attractive; i.e., free of plastics, glass, and stones to ensure its marketability.

Increasingly stringent emissions standards require the reduction of $\mathrm{NO}_{\mathrm{x}}$ or $\mathrm{CO}$ concentrations from co-generation, often requiring the removal of hydrogen sulfide from the biogas. Legislation usually defines the market price of the electricity produced. High prices stimulate the construction of biogas installations (Figure 2). In some European countries, such as Austria and Denmark, the distribution of heat from co-generators is subsidized.

Finally, $\mathrm{CO}_{2}$ and/or energy taxes on fossil fuels influence the profitability of biogas use. However, its impact remains marginal when compared to the politically increased market prices. A realistic economical calculation is possible only when the social costs are internalized. 


\section{Social Cost}

The social or external costs include all liabilities not covered by the purchase price of the energy; i.e., transport risks, impacts on the environment, buildings, human health, accidents, reduction of plant yields, etc. The highest input on the greenhouse effect, for example $(50 \%)$ is caused by $\mathrm{CO}_{2}$ emissions from energy production (including traffic) with fossil fuels. The second most important source is the halogenated hydrocarbons (CFC) with approximately 20\% (Enquete-Commission 1990).

Biomass also adds to the greenhouse effect. Methane and $\mathrm{N}_{2} \mathrm{O}$ produced by livestock, landfills, rice fields, etc. contribute about $15 \%$. Particularly large surfaces with organic material are major sources for the production of methane, $\mathrm{CO}_{2}$, and VOCs. (Lusk 1994) estimated that U.S. livestock manures emit about 3 million metric tons of methane annually, accounting for approximately $10 \%$ of total U.S. methane emissions. Of that, liquid slurry adds about $30 \%$ and the remaining $60 \%$ comes from solid waste. The U.S. Environmental Protection Agency has estimated that about one-third of the emissions might be profitably reduced at the farms.

A recent Austrian study (Steinlechner et al. 1994) demonstrated that 32\% of a total of 411 tons a year of methane emitted derive from MSW disposal, $7 \%$ from the storage of animal manure, and $2.8 \%$ from industrial wastewater. All three types of waste can be easily treated anaerobically under controlled conditions. Hence, AD could prevent up to $40 \%$ of the methane emissions in Austria.

If governments would include external costs in energy prices and support technologies which represent environmental betterment through added income, all renewable energies would immediately have breakthrough.

In Switzerland, these social costs were evaluated (Ott et al. 1994). However, they are voluntarily applied for public construction only. The added costs are conservative estimates (Table 5) and do not necessary reflect the real cost. However, it is more important that they are approximately right than precisely wrong. The only thing that counts is their acceptance and application by the concerned representatives.

Table 5: Social Cost of Energy in Switzerland

\begin{tabular}{||l|c|c||}
\hline \multicolumn{1}{|c|}{ Energy Source } & Actual Price (cents/kWh) & Social Cost (cents/kWh) \\
\hline Electricity & $3.8-17$ & 4.2 \\
Oil (extra light) & $2.0-3.5$ & 6.0 \\
Oil (heavy) & $1.5-3.5$ & 7.0 \\
Natural Gas & $3.0-5.0$ & 4.0 \\
Wood Chips & $3.0-5.0$ & 1.0 \\
\hline
\end{tabular}




\section{Literature}

Danish Energy Agency; 1991, Centralized Biogas Plants in Denmark. Conclusions and recommendations from the main report, $\mathrm{p} 9$.

Edelmann, W. et al.; 1993. Vergarung von hauslichen Abfallen und Industrieabwassern. Bundesamt fur Konjunkturfragen, $p 68$.

Edelmann, W. et al.; 1994. Biogas aus festen Abfallen und Industrieabwassern. Eckdaten fur Planer. Bundesamt fur Konjunkturfragen, p 83.

Enquete-Kommission des deutschen Bundestages; 1990. Schutz der Erde, Teilband I. Verlag C.F. Muller, p 686.

Haskoning; 1993. Conversion Techniques for VGF waste. Developments of 1992.p 121.

Lusk, Ph.; 1994. Methane Recovery from Animal Manures: A Current Opportunities Casebook, p 90.

Ott, W. et al.; 1994. Externe Kosten und kalkulatorische Energiepreiszuschlage fur den Stromund Warmebereich, Bundesamt fur Konjunkturfragen, p 169.

Steinlechner, E. et al.; 1994. Moglichkeiten der Verneidung und Nutzung anthropogener Methanemissionen. Inst. fur Umweltgeologie und Okosystemforschung, p 342. 


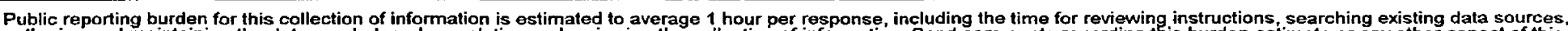

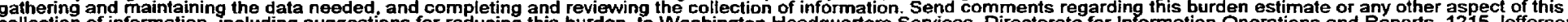

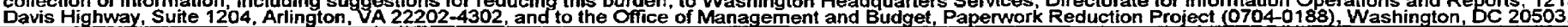
1. AGENCY USE ONLY (Leave blank)
2. REPORT DATE
3. REPORT TYPE AND DATES COVERED
January 1996
NREL Report

4. TITLE AND SUBTITLE

Deploying Anaerobic Digesters: Current Status and Future Possibilities

5. FUNDING NUMBERS

WM513231

6. AUTHOR(S)
P. Lusk, P. Wheeler, C. Rivard

7. PERFORMING ORGANIZATION NAME(S) AND ADDRESS(ES)

National Renewable Energy Laboratory

1617 Cole Boulevard

Golden, CO 80401

\section{SPONSORING/MONITORING AGENCY NAME(S) AND ADDRESS(ES)}

National Renewable Energy Laboratory

1617 Cole Boulevard

Golden, CO 80401-3393
8. PERFORMING ORGANIZATION

REPORT NUMBER

DE96000508

10. SPONSORING/MONITORING AGENCY REPORT NUMBER

NRELTP-427-20558

\section{SUPPLEMENTARY NOTES}

\section{2a. DISTRIBUTIONIAVAILABILITY STATEMENT}

National Technical Information Service

U.S. Department of Commerce

5285 Port Royal Road

Springfield, VA 22161 12b. DISTRIBUTION CODE

UC-1503

\section{ABSTRACT (MaXimum 200 words)}

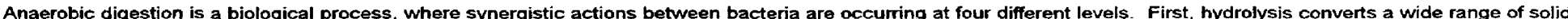

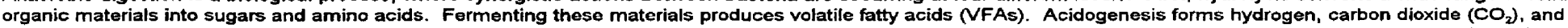

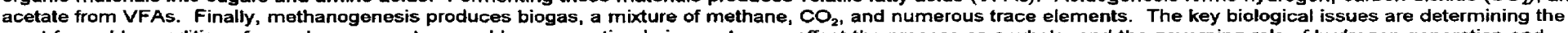

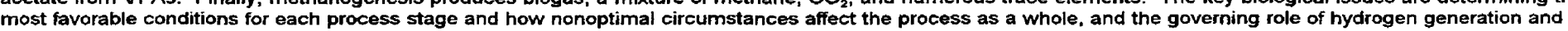
consumption.

\section{SUBJECT TERMS}

anaerobic digestion, biogas, municipal solid waste, green pricing

15. NUMEER OF PAGES

16. PRICE CODE

\section{SECURITY CLASSIFICATION OF REPORT}

18. SECURITY CLASSIFICATION OF THIS PAGE
19. SECURITY CLASSIFICATION OF ABSTRACT
20. LIMITATION OF ABSTRACT

Standard Form 298 (Rev. 2-89) Prescribed by ANSI Std. Z39-1E 